\title{
EWOLUCJA INSTYTUCJI PREZYDENTURY W POLITYCZNEJ HISTORII UKRAINY: USTANOWIENIE PREZYDENTURY, KOMPETENCJE, ROLA I MIEJSCE PREZYDENTA W SYSTEMIE RZĄDÓW
}

ABSTRACT The Evolution of Institution of Presidency in Political History of Ukraine: Incipience, Powers, Role and Place in the System of Government

The author determined phases of formation, powers, role and place of presidency in the government system of Ukraine at different stages of its political development, outlined historiography of presidency's researches in Ukraine, incrementally structured the evolution of political and legal views about the nature and purpose of the presidency in Ukraine, outlined the factual authority, role and place of presidency in the government system of Ukraine (on Ukrainian ethnic territories) in the first decade of the twentieth century. $\mathrm{He}$ also described the influence of the USSR presidency on the characteristics of formation and role of the presidency in post-Soviet Ukraine as well as revealed the dynamics of presidency in the independent Ukraine, 1991-2014. The author also found out the problem of institutional inheritance of presidency (including his powers, role and place in system of government) in the context of impact of some historical milestones of Ukrainian statehood in the following historical milestones. As result, the researcher argued that the institution of presidency in Ukraine (including the government system at all) needs to be reformed because of the past institutional, legal and political legacy of the presidency in Ukraine, and given to the experience of presidency in Central and Eastern Europe countries. 
Słowa kluczowe: prezydent, prezydentura, system rządów, parlamentaryzm, system prezydencki, system półprezydencki

Keywords: president, presidency, system of government, parliamentarism, presidentialism, semi-presidentialism

W skutek demonstracji i masowych protestów ludności mających miejsce na Ukrainie w okresie od listopada 2013 do lutego 2014 r. (początkowo z powodu wstrzymania przez prezydenta i rząd procesów integracji Ukrainy z UE, a następnie w rezultacie systemowego oporu społeczeństwa wobec istniejącego układu politycznego), które przeszły już do historii jako fenomen tzw. „Euromajdanu” i „rewolucji godności”, obalony został dyktatorski ( $w$ formie nasilającego się autorytaryzmu) reżim prezydenta Ukrainy Wiktora Janukowycza. Po tych wydarzeniach system rządów na Ukrainie zmienił się z prezydencko-parlamentarnego na parlamentarno-prezydencki (podobną zmianę system polityczny Ukrainy przeszedł w latach 2004-2006). Znacznie ograniczone zostały kompetencje prezydenta, przynajmniej w kwestii jego udziału w formowaniu i przedterminowym wstrzymaniu kompetencji rządu oraz innych centralnych organów władzy wykonawczej. Wraz z tym, jak również w kontekście spodziewanych przedterminowych wyborów prezydenckich (które zostały wyznaczone na 25 maja 2014 r.) oraz zarówno wewnętrznej (w sytuacji, kiedy budżet państwa został rozgrabiony przez poprzedni reżim, a kraj i społeczeństwo wymagały systemowych i fundamentalnych reform), jak i zewnętrznej polityki (wskutek polaryzacji interesów Ukrainy i Rosji, faktycznej utraty przez tę pierwszą Krymu i nieuznawania przez tę drugą obecnej władzy w Kijowie) został na Ukrainie obrany kurs na przyśpieszone przyjęcie poprawek do konstytucji i co za tym idzie określenie nowego miejsca instytucji prezydentury w systemie politycznym Ukrainy. W tym kontekście aktualne okazało się zagadnienie adekwatnego określenia perspektywicznego systemu rządzenia na Ukrainie, w szczególności miejsca, jakie miała w nim zajmować instytucja prezydentury. Jest to niewątpliwie problem skomplikowany i kompleksowy, a jego rozwiązanie jest faktycznie niemożliwe bez znajomości specyfiki i następstw ewolucji instytucji prezydentury (zwłaszcza w kontekście jej kształtowania się, kompetencji, roli i miejsca w systemie rządów) w politycznej historii Ukrainy.

Instytucja prezydenta na Ukrainie stanowi dość dobrze i wszechstronnie zbadane zagadnienie. Rezultatybadańznajdujemywcałymszereguopracowań, poświęconymkształtowaniu się, uprawnieniom, roli i miejscu prezydenta w systemie politycznym, w szczególności zaś systemowi rządów na Ukrainie. Pierwsze opinie co do celowości wprowadzania instytucji prezydentury na Ukrainie (na historycznych etnicznych ziemiach Ukrainy) znajdujemy w opracowaniach takich autorów, jak H. Andruźkyj ${ }^{1}$, M. Drahomanow ${ }^{2}$,

1 П. Біленчук, В. Капелюшний, Георгій Андрузький: провидецъ, патріот, конституціоналіст, „Вісник Академії праці і соціальних відносин Федерації профспілок України" 2002, Vol. 2, nr 15, s. 2-12.

2 М. Арагоманов, Пегеdнє слово до „Громади”, [w:] tenże, Вибрані твори. Збірка політичних творів з примітками, Прага-Нью-Йорк 1937, s. 93-147. 
I. Franko ${ }^{3}$, M. Michnowskí, M. Hruszewski ${ }^{5}$, D. Doroszenko ${ }^{6}$, S. Dnistrianśkyj ${ }^{7}$ i in. Kontekst historii ustanowienia instytucji prezydentury na Ukrainie jest przedmiotem prac takich naukowców, jak M. Pachomowa ${ }^{8}$, W. Szatiło 9 , S. Ahafonow ${ }^{10}$, P. Muzyczenko ${ }^{11}$, B. Demjanenko ${ }^{12}$, P. Płachotniuk i W. Melnyczenko ${ }^{13}$, W. Suchonos ${ }^{14}$, B. Łazariew $^{15}$, I. Star$\mathrm{kiw}^{16}$, M. Tomenko ${ }^{17}$, W. Horbatiuk ${ }^{18}$, W. Szapował i W. Hołowatenko ${ }^{19}$, O. Żytnyk ${ }^{20}$, T. Pryjmak ${ }^{21}$, M. Mackewycz ${ }^{22} \mathrm{i}$ in. (wskazano przeważnie prace opublikowane po 2000 r.).

3 I. Франко, „Громада” $i$ „за друга” сегеd украйнського народу в Галичині $і$ на Буковині, [w:] tenże, Зібрання творів. У 50 т., Київ 1984, Vol. 44, nr 1, s. 487-495.

4 Основний закон „Самостійної України” Спілки народу українського, [w:] Iсторіз української конституціï, red. А. САюсаренко, М. Томенко, Київ 1997.

5 М. Грушевський, На порозі нової України (фрагменти), [w:] Громадянин-Аержава-Громадянське виховання. Антологія, red. М. Рагозін, О. Сухомлинська, Аонецьк 2001, s. 74-85.

6 А. Аорошенко, Аоба Центральної Ради - Історія України. 1917-1923 рр., Vol. 2, Ужгород 1932.

7 П. Стецюк, Станіслав Аністрянський як конституціоналіст, Аьвів 1999.

8 М. Пахомова, Формування інституту президентської влади в Україні, „Наукові праці. Науковометодичний журнал" 2004, Vol. 33, nr 20: Політичні науки, s. 21-26.

9 В. Шатіко, Інститут глави держави: його місие в украйнському конституціоналізмі XIX - поч. XX cm., „Віче” 1999, Vol. 10, s. 137-144.

10 С. Агафонов, Історичий розвиток інституту глави держави в Украйні, „Право України” 2001, Vol. 7, s. 102-105.

11 С. Агафонов, Історичний розвиток інституту глави держави в Україні, „Право України” 2001, Vol. 7, s. 102-105.

12 Б. Аем'яненко, Генезис інституту президентства в Україні: попегедні підсумки президентської каденції В. Ющенка, „Сучасна українська політика: політики і політологи про неї: зб. наук. праць” 2010, Vol. 19, s. 24-38.

13 П. Пцахотнюк, В. Мельниченко, Інститут президенства в Україні: становлення та розвиток: монографія, Київ 2004.

14 В. Сухонос, Інститут глави держави в Україні 1917-1921 років, „Вісник ЦВК” 2008, Vol. 4, nr 14, s. 78-84.

15 Б. Аазарев, Президент СССР, „Государство и право” 1990, Vol. 7, s. 3-14; tenże, Об изменениях в правовом статусе Президента СССР, „Государство и право” 1991, Vol. 8, s. 32-44.

16 I. Старків, Історико-правові витоки інституту президентства в Україні та світі, „Форум права" 2012, Vol. 4, s. 859-864.

17 М. Томенко, Інституту президентства в украӥнській історико-політичній думщі, „Українська перспектива: історико-політологічні підстави сучасної державної стратегії" 1995, Vol. 2, s. 17-28.

18 В. Горбатюк, Інститут президентства в Україні: історико-правовий аспект, „Часопис Київського університету права” 2011, Vol. 2, s. 325-329.

19 В. Шаповац, В. Головатенко, Інститут глави держави в українському конституціоналізмі кіния $X I X$ - початку XX cm., „Вісник Академії правових наук України” 1997, Vol. 2, nr 9, s. 49-55.

20 О. Житник, Інститут глави держави в політико-правовій думщі доби украӥнського нащіонального відродження (друга половина XIX cm. - 1917 р.), „Часопис Академії адвокатури України” 2010, Vol. 9, nr 4, s. 1-5.

21 Т. Приймак, Конституційний проект М. Грушевського з 1905 р., „Український історичний журнал" 1991, Vol. 1, s. 127-136.

22 М. Мацкевич, Конституційне законодавство в ЗУНР: історико-правові аспекти, „Право України" 2011, Vol. 2, s. 255-261. 
Status polityczno-prawny i kompetencje prezydenta na Ukrainie stały się przedmiotem aktów normatywno-prawnych oraz całego szeregu opracowań naukowych autorstwa m.in. takich uczonych, jak (wskazano prace wydane po roku 2001): O. Zozula ${ }^{23}$, S. Ahafonow ${ }^{24}$, F. Burczak ${ }^{25}$, W. Suchonos ${ }^{26}$, N. Zajać ${ }^{27}$, M. Zelinska ${ }^{28}$, M. Karmazina ${ }^{29}$, W. Melnyczenko ${ }^{30}$, J. Todyka ${ }^{31}$, S. Derewjanko ${ }^{32}$, O. Wołoszczuk ${ }^{33}$, W. Pohoriłko ${ }^{34}$, O. Procyk ${ }^{35}$, W. Szapowat ${ }^{36}$,

23 О. Зозуля, Інститут президентства як об’єкm сучасної конституиійної реформи в Україні, „Форум права” 2010, Vol. 1, s. 126-146; tenże, Секретаріат Президента України: нормативноправові засади організації та діяльності: монографія, red. О. Марцемяк, Харків 2008; tenże, Правовий статус Президента України як глави держави і глави виконавчої влади, „Науковий вісник Ужгородського національного університету. Право” 2008, Vol. 11, s. 139-146; tenże, Канщелярія Президента України: правові засади побудови апарату глави держави, „Форум права” 2008, Vol. 2, s. 152-182.

С. Агафонов, Правовий статус Президента Украӥни, „Право України” 2000, Vol. 9, s. 25-27.

Ф. Бурчак, Президент України, Київ 1997; Ф. Бурчак, В. Погорілко, Конституційно-правовий статус Президента України, [w:] Конституційне право України, red. В. Тація, В. Погорікка, I. Тодики, Київ 1999, s. 220-237.

В. Сухонос, Інститут глави держави в конституційному праві. Монографія, Суми 2011, s. 221-280.

Н. Заяць, Теоретико-правові проблеми інституту президентства в механізміреалізацїдержавної влади в Україні, „Право України” 2009, Vol. 6, s. 29-37.

М. Зелінська, Етапи трансформаиї інституту президентства в Україні, „Політичний менеджмент" 2010, Vol. 1, s. 68-75; taż, Можливі моделі розвитку інституту президентства в Україні, „Політичний менеджмент” 2007, Vol. 3, s. 69-77.

М. Кармазіна, Еволюиіл структури президентського Секретаріату, „Політичний менеджмент” 2009, Vol. 3, s. 60-68; taż, Президентство: украӥнський варіант, Київ 2007.

30 В. Мельниченко, Інститут Президента в Україні: стан та перспективи розвитку, „Право України" 2009, Vol. 12, s. 18-29; В. Мельниченко, Н. Пкахотнюк, Повноваження Президента України у контексті конституційної реформи: структура, зміст, характер, „Бюлетень Міністерства Юстиції України” 2005, Vol. 12, s. 5-15.

31 I. Тодика, Президент України: конституиійно-правовий статус: монографія, Харків 1999; И. Тодика, В. Яворский, Президент Украины: конституционно-правовой статус: монография, Харьков 1999.

32 С. Аерев'янко, Про уточнення повноважень Президента України щодо призначення/проголошення всеукраїнського референдуму в оновленій Конституції України, „Вісник Центральної Виборчої Комісії" 2009, Vol. 2-3, nr 16-17, s. 63-71.

33 О. Волощук, Теоретичні та практичні проблеми організаиї інституту виборів Президента України, „Вісник Центральної Виборчої Комісії 2009, Vol. 1, nr 15, s. 53-59.

34 В. Погорілко, Теоретичні проблеми конституиійного статусу Президента України, [w:] Проблеми реалізації Конститущії України: теорія і практика. Монографія, red. tenżе, Київ 2003, s. 304-349; tenże, Інститут президентства в Україні, [w:], Державотворення і правотворення в Україні: досвід, проблеми, перспективи. Монографія, red. І. Шемшученко, Київ 2001, s. 113-134.

35 O. Protsyk, Ruling with Decrees: Presidential Decree Making in Russia and Ukraine, „Europe-Asia Studies” 2004, Vol. 56, nr 5, s. 637-660, [online] http://dx.doi.org/10.1080/0966813041000235 083; tenże, Constitutional Politics and Presidential Power in Kuchma's Ukraine, „Problems of Post-Communism" 2005, Vol. 52, nr 5, s. 23-31, [online] http://dx.doi.org/10.1080/10758216.2005.11 052212 .

36 В. Шаповал, Статус Президента и исполнительная власть в Украине, [w:] Проблемь гармонизачии законодательства Украинь і стран Европь, red. Е. Кубко, В. Цветкова, Киев 2003. 
O. Poliszczuk ${ }^{37}$, Ł. Krywenko ${ }^{38}$, R. Martyniuk ${ }^{39}$, J. Bernaziuk ${ }^{40}$, I. Żylajew ${ }^{41}$, T. Trijniak ${ }^{42}$, P. Rudyk ${ }^{43}$, P. Sinelnik ${ }^{44}$, H. Makarow ${ }^{45}$, O. Bałahura ${ }^{46}$, M. Cwik i I. Prociuk ${ }^{47}$, W. Hołowatenko ${ }^{48}$. W wymiarze porównawczo-prawnym i porównawczo-politologicznym podobne kwestie były przedmiotem poszukiwań następujących uczonych: T.Żalij ${ }^{49}$, J. Barabasz ${ }^{50}$, Ł. Hałahan ${ }^{51}$, W. Haponenko ${ }^{52}$, O. Dudnyk ${ }^{53}$, O. Kordun, K. Waszczenko i R. Pawłenko ${ }^{54}$,

37 О. Поліщук, Конституційно-політична модернізаиіл інституту президента в Украйні, „Вісник ХНУ імені В. Н. Каразіна. Питання політології” 2013, Vol. 1073, s. 19-25.

38 А. Кривенко, Президент Украӥни: конституиійно-правовий статус, „Віче” 1993, Vol. 12.

39 Р. Мартинюк, Проблеми визначення конститущійно-правового статусу Президента України в умовах змішаної форми правління, „Право України” 2009, Vol. 5, s. 44-50; tenże, Аналіз функщіональної природи інституту президента в Україні, „Часопис Київського університету права” 2008, Vol. 2, s. 80-85.

40 І. Берназюк, Послання Президента України до народу та до Верховної Ради України як офіиійні документи (акти) глави держави, „Форум права” 2010, Vol. 4, s. 63-68.

41 І.Жимяєв, Послання Президента Україниякінструмент стратегічного управління, „Економічний часопис" 2006, Vol. 5-6, s. 21-24; tenże, Послання Президента України як інструмент державної політики, „Стратегічні пріоритети” 2007, Vol. 1, nr 2, s. 24-33.

42 Т. Трійняк, Деякі аспекти конституційної відповідальності Президента України, [w:] Аругі конститущійні читання, Харків 2009.

43 П. Рудик, Ао питання нового статусу Президента України в контексті конституційних змін, „Часопис Київського університету права” 2008, Vol. 2, s. 69-74.

44 С. Сінельник, Аискреиійні повноваження президента України в контексті проведення конститущійної реформи, „Вісник Запорізького національного університету. Юридичні науки” 2009, Vol. 1, s. 62-68.

45 Г. Макаров, Нормотворча діяльність глави держави: зарубіжний досвід та вітчизняна практика, „Стратегічні пріоритети” 2009, Vol. 1, nr 10, s. 5-13.

46 О. Балагура, Институт президентства в Украине: практика становлении, „Проблеми права на змамі тисячоліть" 2001, s. 82-86.

47 О. Балагура, Институт президентства в Украине: практика становлении, „Проблеми права на змамі тисячоліть" 2001, s. 82-86.

В. Головатенко, Окремі аспекти конституиійно-правового статусу Президента України, „Право України" 1999, Vol. 5, s. 30-34.

49 Т. Жалій, Правовий статус глав держав в Украӥні та Російській Федерації: порівняльний аналіз, „Науковий вісник Херсонського державного університету. Юридичні науки” 2013, Vol. 1, s. 14-18.

50 Й. Барабаш, Президент у змішаних республіках: деякі питання конституиійно-правової теорї та практики, „Право України” 2012, Vol. 8, s. 93-99; tenże, Iмпічмент як форма конституційноправової відповідальності $і$ засіб урегулювання державно-правових конфліктів, „Проблеми законності" 2008, Vol. 96.

$51 \Lambda$. Галаган, Президент у системі влади за різних форм державного правління, „Політичний менеджмент" 2011, Vol. 4, s. 8-17.

52 В. Гапоненко, Суперечності інституту президентства: теоретичні засади та уроки для України, „Політичний менеАжмент” 2011, Vol. 5, s. 110-116.

53 О. Аудник, Трансформація інституту президентства в країнах СНА (2005-2006 роки), „Політичний менеАжмент” 2007, s. 214-227.

54 О. Кордун, К. Ващенко, Р. Павленко, Особливості виконавчої влади в пострадянській країні. Монографis, red. О. Корауна, Київ 2000. 
I. Kresina, A. Kowałenko i O. Bałan ${ }^{55}$, D. Mazur ${ }^{56}$, N. Dius ${ }^{57}$, W. Krejdenko ${ }^{58}$, O. Wołoszczuk $^{59}$, S. Seriohina ${ }^{60}$, A. Riazancew ${ }^{61}$, D. Kowryżenko ${ }^{62}$, D. Biełow ${ }^{63}$, W. Szatiło ${ }^{64}$, N. Borysow ${ }^{65} \mathrm{i}$ in.

Miejsce i rola prezydenta w systemie władzy państwowej (systemie rządzenia państwem) stały się przedmiotem naukowych opracowań takich naukowców, jak: W. Kafarśkyj ${ }^{66}$, S. Seriohina $^{67}$, M. Cwik i N. Żun ${ }^{68}$, W. Szatiło ${ }^{69}$, R. Martyniuk ${ }^{70}$, E. Skrebec ${ }^{61}$, R. Bezsmertnyj ${ }^{72}$,

55 І. Кресіна, А. Коваленко, О. Балан, Інститут імпічменту: порівняльний політико-правовий аналіз, Київ 2004.

56 А. Мазур, Правові акти президентів України і Росї та їх класифікація: теоретико-правовий аспект, „Вісник Нац. ун-ту внутр. справ” 2004, Vol. 27, s. 230-237.

57 Н. Аіус, Інститут імпічменту в Украйні, Францї та Російській Федераціӥ: порівняльно-правовий aсnекm, „Науковий вісник Ужгородського національного університету. Право” 2007, Vol. 8.

В. Крейденко, Інститут президентства в Україні: порівняльнй аналіз 2004-2012 pp., „Ефективність Аержавного управління” 2012, Vol. 30, s. 151-157.

О. Волощук, Інститут президента у Франції, Росї та Україні: конституційні норми і політична практика:монографія, Чернівці 2009; tenże, Президент - активний учасникзаконодавчого прочесу (порівняльний аналіз конститущійно-правових норм Францї, Росї̈ та України), „Науковий вісник Ужгородського університету. Право" 2002, Vol. 1, s. 56-61.

С. Серьогіна, Теоретико-правові та організаційні засади функціонування інституту президентства в Україні: монографія, Харків 2001.

61 А. Рязанцев, Роль института президентства в процессе формирования исполнительной власти в России и Украине (сравнительный анализ), „Вестник ВГУ: История. Политология. Социология” 2013, Vol. 1, s. 146-148.

62 А. Ковриженко, Інститут вето: зарубіжний досвід, національне законодавство і практика, пропозиції, Київ 2009.

63 А. Бєлов, І. Бисага, Конституційно-правове регулювання інституту президентства в Україні та Францї, Ужгород 2007.

64 В. Шатимо, Институт президентства в механизме государственной власти зарубежньх стран и Украиныь, „TEISE” 2014, Vol. 90, s. 235-252.

65 Н. Борисов, Институт Президента Украинь: долгий путь к институционализации, „Грани” 2013, Vol. 3, s. 40-57.

66 В. Кафарський, На відміну від елітного акиіонерного клубу $і$ від монарха. Політичні партії і Президент: иляхи співпрачі, „Віче” 2006, Vol. 17-18, s. 77-80.

67 С. Серьогіна, Оптимізація статусу президента як ключова ланка конституційної реформи України, „Право України” 2009, Vol. 6, s. 23-28.

68 М. Цвік, Н. Жук, Аинаміка президентської влади в Україні, „Вісник академії правових наук України" 2007, Vol. 3, nr 46, s. 33-44.

69 В. Шатімо, Інститут президентства в системі державної влади України, Київ 2004; tenże, Нормативно-правовые и другие акть президента Украиньь в механизме реализачии государственной власти, „TEISË” 2013, Vol. 87, s. 217-230.

70 Р. Мартинюк, Президент України в системі стримувань і противаг на сучасному етапі, „Підприємництво, господарство і право” 2008, Vol. 8, s. 28-31.

71 Е. Скребец, Практика применения института вето главь государства и стабильность политической системы Украиныь, „Вестник СевГТУ. Политология” 2003, Vol. 52, s. 226-235.

72 Р. Безсмертний, Президент України і Верховна Рада України, „Віче” 2000, Vol. 7, nr 100, s. 34-38. 
O. Tkaczenko ${ }^{73}$, W. Holowatenko ${ }^{74}$, I. Czeker ${ }^{75}$, P. Maniuk ${ }^{76}$, A. Seliwanow i W. Susłow $^{77}$, O. Sowhyria ${ }^{78}$, Ł. Polakowa ${ }^{79}$, W. Potapenko ${ }^{80}$, S. Bołydriew i B. Rebrysz ${ }^{81}$, O. Zozula ${ }^{82}$, J. Bernaziuk ${ }^{83}$, O. Danylak ${ }^{84}$, N. Żuk ${ }^{85}$, O. Wołoszczuk ${ }^{86}$, S. Wawrzenczuk $^{87}$, F. Wenisławśkyj ${ }^{88}$, W. Hniłorybow ${ }^{89}$, A. Hulijew ${ }^{90}$.

73 О. Ткаченко, Вето Президента: основи, практика, „Голос України” 1999, Vol. 142, s. 2-3.

74 В. Головатенко, Право вето Президента Україн: складова механізму стримувань і противаг чи дестабілізуючий чинник законотворення?, „Українське право” 2000, Vol. 1, s. 105-109.

75 I. Cheker, Comparative Analysis of Problematic Aspects of the President Impeachment Procedure in Ukraine and Russia, [w:] Aкадемічні та наукові виклики різноманітних галузей знань у XXI столітті, cz. 1, Харків 2012, s. 73-77.

76 П. Манюк, Право вето президента України у контексті правової охорони конститущї України, „Порівняльно-аналітичне право” 2013, Vol. 3, nr 2, s. 87-89.

77 А. Селіванов, В. Суслов, Право президентського вето у контексті відносин з парламентом, „Голос України” 1996, Vol. 105-106, s. 7.

78 О. Совгиря, Інститут контрасигнування актів глави держави в Україні: правова природа та проблеми законодавчого регулювання, „Вісник Київського національного університету імені Тараса Шевченка. Юридичні науки" 2010, Vol. 85, s. 66-70.

79 А. Полякова, Особливості взаємодії президента України, законодавчої влади з судовою владою (1991-2004 рр.), „Наукові праці історичного факультету Запорізького національного університету" 2013, Vol. 35, s. 220-224.

80 В. Потапенко, Президент України і судова влада: деякі аспекти взаємодї̈, „Проблеми законності” 2010, Vol. 110, s. 263-272.

81 С. Болдирєв, Б. Ребриш, Підстави проведення імпічменту глави держави за Конституцією України: перспективи удосконалення, „Аержавне будівництво та місцеве самоврядування” 2012, Vol. 23, s. 106-115.

82 О. Зозуля, Теорія та практика взєємодї Секретаріату Президента України з Верховною Радою України, „Право і безпека” 2007, Vol. 6, nr 2, s. 32-39.

83 І. Берназюк, Реалізаиія Президентом України права вето щодо прийнятих Верховною Радою України законів: деякі аспекти, „Порівняльно-аналітичне право” 2013, Vol. 1, s. $49-54$.

О. Аанимяк, Порівняльний аналіз механізмів стримувань $і$ противаг між Президентом, парламентом та Урядом Украйни у владних моделях 1996 та 2004 років, „Вісник Національної академії державного управління. Політологія і право” 2011, Vol. 2, nr 2, s. 174-181.

Н. Жук, Парламент, президент, уряд: через взаємостримування до рівноваги. Монограбія, Харків 2007.

О. Волощук, Повноваження президента Украйни щодо судової влади, „Науковий вісник Чернівецького університету. Правознавство” 2011, Vol. 575, s. 46-50; tenże, Конституційні проблеми взаємовідносин Президента та виконавчої влади, „Аержава і право” 2004, Vol. 26, s. 184-190; tenże, Місие Президента у механізмі державної влади, „Бюметень Міністерства Юстиції України” 2011, Vol. 12, s. 23-33.

С. Вавженчук, Виконавча влада - Президент Украйни: конституційно-правові аспекти структурної взаємодї, „Аержава і право” 2005, Vol. 30, s. 246-255.

88 Ф. Веніславський, Роль Президента України в механізмі забезпечення взаємодї законодавчої і виконавчої гілок влади, „Нова політика” 1998, Vol. 1, s. 7-11.

89 В. Гнілорибов, Проблеми взаємовідносин Верховної Ради України та Президента України, [w:] Парламентаризм в Україні: теорія і практика, Київ 2001, s. 157-162.

90 А. Гулиев, Институт президентства в противодействии международному терроризму: сравнительно-правовой анализ законодательства Украины и Азербайджанской Республики, Киев 2012. 
Według stanu na 2014 r. po raz ostatni w sposób kompleksowy problematykę instytucji prezydentury Ukrainy w systemie władzy państwowej (poprzez odwołanie się do miejsca i roli prezydenta w państwowej administracji Ukrainy, doświadczenia funkcjonowania instytucji prezydentury w młodych państwach znajdujących się w okresie transformacji i po tym okresie, określenia instytucji prezydentury w systemie określenia i realizacji priorytetów rozwoju systemu społecznego w okresie transformacji na Ukrainie, określenia prawnych aspektów funkcjonowania instytucji prezydentury na Ukrainie i jej wpływu na kształtowanie konstytucyjnego ustroju Ukrainy) nakreślono w materiałach z konferencji naukowej wydanych przez Kijowski Uniwersytet Narodowy im. Tarasa Szewczenki w 2014 r. ${ }^{91}$

Jednak nawet w zaproponowanym przeglądzie literatury naukowej, poświęconej instytucji prezydentury na Ukrainie, niewyjaśniona czy też bardzo słabo wyjaśniona została kwestia instytucjonalnego dziedziczenia instytucji prezydentury - w szczególności jej uprawnień, roli i miejsca w systemie rządzenia - w kontekście historycznego wpływu jednych historycznych etapów kształtowania się ukraińskiej państwowości na następne. Rozpatrzenie właśnie tej problematyki w kontekście kształtowania się instytucji prezydentury na Ukrainie będzie głównym celem niniejszego opracowania.

Zanim jednak przejdziemy bezpośrednio do analizowania ewolucji instytucji prezydentury w historii politycznej Ukrainy, należy wspomnieć, że sama instytucja prezydentury $^{92}$ we współczesnym jej rozumieniu po raz pierwszy została formalnie wprowadzona przez Konstytucję USA w 1787 r. Dziś prezydentura jest jedną z najbardziej rozpowszechnionych instytucji władzy państwowej w świecie. Na przykład pod koniec XX w. ponad 130 ze 183 (współczesnych) państw będących członkami ONZ miało w swoim mechanizmie państwowym stanowisko prezydenta ${ }^{93}$, co istotne jednak, w każdym państwie, w którym funkcjonuje instytucja prezydentury, przeszła ona szczególną i specyficzną ewolucję.

Wprowadzanie (widzianego jako proces wielostopniowy i skomplikowany) instytucji prezydentury na Ukrainie zostało podyktowane historycznym dążeniem ukraińskich ziem etnicznych do przekształceń demokratycznych i ma swoje tradycje. Ukraińska myśl polityczno-prawna wiąże ideę instytucji głowy państwa przede wszystkim z wyobrażeniami o tej czy innej formie (monarchicznej i republikańskiej) i systemie (prezydenckim, półprezydenckim czy parlamentarnym) rządzenia państwem ${ }^{94}$. Tak więc jeszcze w połowie i pod koniec XIX w. w kręgach społeczno-politycznych ukraińskiej inteligencji powstał narodowo-państwowy kierunek myśli polityczno-prawnej, którego przedstawiciele jako pierwsi próbowali przygotować projekty konstytucji Ukrainy i określić istotę stanowiska

91 Iнститут Президента України в системі державної влади України: матеріали наукової конференцї, Київ 2014.

92 Zgodnie ze słowami A. Hulijewa za instytucję prezydentury należy uważać całokształt państwowo-prawnych (konstytucyjno-prawnych) norm regulujących porządek wyborów i obejmowania stanowiska (inaugurację) prezydenta, uprawnienia prezydenta, wyznaczających jego miejsce i rolę w systemie władz państwa, a także specyfikę przedterminowego wstrzymania kompetencji, zastępstwa i usunięcia ze stanowiska. А. Гулиев, Институт президентства..., s. 146.

93 Н. Сахаров, Институт президентства в современном мире, Москва 1994, s. 3

94 В. Шаповац, В. Головатенко, Інститут глави держави..., s. 49-55. 
głowy państwa na Ukrainie z uwzględnieniem jej tradycji państwowo-historycznych ${ }^{95}$. Idea wprowadzania instytucji prezydentury w ukraińskiej myśli polityczno-prawnej zrodziła się w czasach działalności Bractwa Cyrylo-Metodiańskiego (lata 1845-1847), którego członkowie opowiadali się za budową słowiańskiego związku chrześcijańskich republik; na czele każdej z nich (w tym także Ukrainy) powinni stać - wybrani na pewien określony czas przez zgromadzenie ogólnonarodowe - prezydent (jako głowa państwa) oraz sejm (jako parlament) ${ }^{96}$. Projekt Konstytucji Republiki z roku 1850, którego autorem był członek Bractwa H. Andruźkyj ${ }^{97}$, stał się bodaj pierwszym doniosłym dokumentem o charakterze konstytucyjno-prawnym w ukraińskiej myśli politycznej połowy XIX w., w którym zwrócono uwage przede wszystkim na konieczność wprowadzania republikańskiej formy rządów ze stanowiskiem prezydenta jako członka Rady Państwa (organu ustawodawczego). Następnym krokiem w procesie uzasadnienia wprowadzenia stanowiska prezydenta i jego niezbędności dla Ukrainy (nadal jednak w składzie republiki federacyjnej) stały się opracowania M. Drahomanowa - w szczególności praca Wolny zwiazek - Wolne towarzystwo (Вольний Союз - Вільна Спілка, 1884), gdzie pojawia się argumentacja, że prezydent jest odpowiedzialną politycznie instytucją władzy, w której skupione zostały funkcje ogłaszania, nadzoru nad wykonaniem, a także ścigania za naruszenie ustaw przyjętych przez parlament ${ }^{98}$. Nie mniej ważne okazały się opinie I. Franki, który uzasadniał ideę obieralnej głowy państwa, służącej swojemu narodowi, opowiadając się za republikańską formą rządów ${ }^{99}$. Problem uzasadnienia instytucji obieralnego prezydenta okazał się bardzo znaczący również w działalności pierwszych ukraińskich partii politycznych działających pod koniec XIX i na początku XX w. Znalazło to wyraz w programach Ukraińskiej Socjaldemokratycznej Partii Robotniczej, Ukraińskiej Partii Socjalistów-Federalistów (połączyła ona członków Ukraińskiej Partii Demokratycznej i Ukraińskiej Partii Radykalnej), Ukraińskiej Partii Socjalistów-Rewolucjonistów i inych, które występowały z postulatem przekształcenia ówczesnego Imperium Rosyjskiego w republikę federacyjną z obieralnym w parlamencie czy też mianowanym przez rząd prezydentem na czele ${ }^{100}$. Na przykład w programie Ukraińskiej Partii Socjalistów-Federalistów podkreślano, że stanowisko prezydenta powinni sprawować kolejno członkowie Wysokiej Rady Państwa (czyli rządu), każdy z nich przez jeden rok ${ }^{101}$.

Nieco odmienny okazał się program Ukraińskiej Partii Ludowej, której dokument programowy Ustawa Zasadnicza „Samostijna Ukrajina" M. Michnowskiego negował idę̨ samorządu lokalnego Ukrainy w ramach rosyjskiego zdecentralizowanego państwa, skupiając się natomiast na postulacie pełnej niepodległości Ukrainy jako repu-

95 Багатопартійна украӥнська держава на початку XX століття: партійні документи перших украӥнських політичних партій, Київ 1992.

Кирило-Мефодївське товариство, Vol. 2, Київ 1990, s. 569-570.

97 П. Біленчук, В. Капемюшний, Георгій Андрузький..., s. 2-12.

98 М. Арагоманов, Переднє слово..., s. 93-147.

99 I. Франко, „Громада” $i$ „за друга”..., s. 487-495.

100 О. Житник, Інститут глави держави..., s. 1-5.

101 М. Пахомова, Формування інституту президентської влади..., s. 21. 
bliki prezydenckiej z obieranym na sześć lat w wyborach powszechnych prezydentem, który miał być zarówno głową państwa, jak i przewodniczącym struktur władzy wykonawczej ${ }^{102}$. Podkreślano, że osoba prezydenta powinna być objęta immunitetem politycznym, ponieważ odpowiedzialność za działania prezydenta powinni ponosić bezpośrednio przez niego mianowani (bez zgody dwuizbowego parlamentu) ministrowie. Ustalono, że na prezydenta może być wybrana osoba w wieku co najmniej trzydziestu pięciu lat. Wprowadzono także normę, że prezydent - nieposiadający prawa weta ustawodawczego - miał pełnić nadzór nad wykonywaniem ustaw, mógł zwoływać dwie izby parlamentu, miał być głównodowodzącym sił zbrojnych Ukrainy, został obdarzony prawem do ułaskawiania (amnestii) itp. W projekcie Konstytucji Ukrainy zaproponowanym przez Ukraińską Partię Ludową został zawarty mechanizm pociągania prezydenta do odpowiedzialności w razie naruszenia przez niego Ustawy Zasadniczej. W tym celu przewidziano powołanie specjalnego sądu ludowego, składającego się z przedstawicieli dwóch izb parlamentu, który miałby prawo usunąć prezydenta ze stanowiska i rozpisać przedterminowe wybory prezydenckie.

Myśl polityczno-prawna Ukrainy okresu połowy XIX-początku XX w. skupiła się faktycznie na wyborze między prezydenckim a parlamentarnym modelem republikanizmu, a co za tym idzie - między stanowiskiem wybieranego w wyborach powszechnych na określony czas prezydenta jako równocześnie głowy państwa i osoby stojącej na czele władzy wykonawczej a stanowiskiem wybieranego przez parlament na określony czas prezydenta wyłącznie jako głowy państwa. Na początku XX w. (zwłaszcza w latach 1918-1921) problem na płaszczyźnie teoretycznej i praktycznej - jak świadczy o tym doświadczenie historyczne - został rozstrzygnięty niejednoznacznie. $Z$ jednej strony w Ukraińskiej Republice Ludowej (URL), w której po raz pierwszy zaakceptowano w praktyce instytucję ukraińskiej prezydentury ${ }^{103}$ (propagatorem tego rozwiązania był M. Hruszewski ${ }^{104}$ ), przewidywano, że osoba, która została wybrana przez zgromadzenie ogólnonarodowe (parlament), jest głową państwa (czyli prezydentem) URL ${ }^{105}$. I. Starkiw $^{106}$ uważa, że 29 kwietnia 1918 r. na stanowisko pierwszego prezydenta URL wybrano M. Hruszewskiego. Jednakże D. Biełow zauważa, że w tym czasie instytucja prezydentury jako taka jeszcze nie istniała ${ }^{107}$. Było to związane z tym, że wybory, w których wybrany został M. Hruszewski, nie były legalne, nie istniały przecież akty normatywno-prawne (choćby nawet ze względu na przyjętą 29 kwietnia 1918 r. Konstytucję URL ${ }^{108}$ ),

\footnotetext{
102 Основний закон „Самостійної України”...

103 С. Агафонов, Історичний розвиток..., s. 103.

104 Т. Приймак, Конституиійний проект..., s. 127-136.

105 И. Тодика, В. Яворский, Президент Украиньк.., s. 65; П. Христюк, Замітки і матеріали до історії української револючї 1917-1920 pp., Vol. 2, Прага 1921, s. 175.

106 І. Старків, Історико-правові витоки..., s. 859.

107 А. Бєлов, І. Бисага, Конституційно-правове регулювання..., s. 74-75.

108 Конституиіз Української Народної Республіки (Статут про державний устрій, права і вільності УНР), [w:] П. Христюк, Замітки і матеріали..., Vol. 2, s. 174-180; А. Аорошенко, Доба Центральної Ради..., Vol. 2, s. 56-57.
} 
które przewidywałyby stanowisko prezydenta i regulowały tryb jego wyboru ${ }^{109}$. Dlatego też słuszniej byłoby uważać za pierwszego prezydenta URL, co prawda już na emigracji, A. Liwyckiego, który piastował to stanowisko dwukrotnie - w latach 1926-1948 i 1948-1954. Innymi prezydentami URL na uchodźstwie (szczegóły zob. tab. 1) byli S. Wytwyćkyj (1954-1965), M. Liwyćkyj (1967-1989) i M. Pławiuk (1989-1992).

Dość specyficzna sytuacja powstała w kontekście określenia głowy państwa w URL w okresie Dyrektoriatu (w latach 1918-1920 na terytorium współczesnej Ukrainy, a w okresie 1921-1926 poza granicami etnicznego terytorium Ukrainy, na emigracji). Dyrektoriat URL był najwyższym organem władzy państwowej Ukraińskiej Republiki Ludowej, który składał się z Przewodniczącego Dyrektoriatu (w latach 1918-1919 był nim W. Wynnyczenko, w latach 1919-1926 - S. Petlura) oraz członków Dyrektoriatu (łącznie pięć osób). Stoimy na stanowisku, że Dyrektoriat, jeśli idzie o uprawnienia i funkcje, przypominał instytucję kolegialnej prezydentury, podporządkowanej i obieranej przez organy władzy ustawodawczej. Najwyższym tymczasowym organem ustawodawczym władzy URL w 1919 r. był Kongres Pracy Ukrainy, przed którym formalnie nawet pomimo faktu, że Kongres Pracy został zwołany przez Dyrektoriat i pracował nie stale, a w trybie sesyjnym - odpowiedzialny był ten ostatni. Specyfika funkcji Dyrektoriatu polegała w tym czasie na tym, że z uwagi na stan wojny ten organ kolegialny władzy państwowej wydawał ustawy, które powinny były być zatwierdzane na najbliższej sesji przez Kongres Pracy Ukrainy (faktycznie zaś oznaczało to, że Dyrektoriat miał prawo wydawać dekrety z mocą prawa). Jako organ władzy wykonawczej funkcjonowała mianowana przez Dyrektoriat (kolegialną głowę państwa URL) i podlegająca kontroli ze strony Kongresu Pracy Ukrainy (parlamentu URL ${ }^{110}$ ) Rada Ministrów Ludowych (rząd URL) z szefem Rady Ministrów Ludowych (premierem URL) na czele. W listopadzie 1920 r. podstawą prawną systemu politycznego URL były ustawy „O tymczasowym Najwyższym Kierownictwie i trybie ustawodawstwa w URL” ${ }^{111}$ oraz „O Państwowej Radzie

109 Tak zwany „mit o M. Hruszewskim jako pierwszym prezydencie Ukrainy” w opinii publicznej (czy społecznej) i polityczno-prawnej Ukrainy został wprowadzony przez D. Doroszenkę w latach 30. XX w. Dokładnie zob.: А. Аорошенко, Історія України. 1917-1923 рр. Українська гетьманська держава 1918 р., Ужгород 1930, s. 35. Z formalnoprawnego i naukowego punktu widzenia M. Hruszewski nie był prezydentem URL, bo w kwietniu 1918 r. takie stanowisko w tym państwie nie istniało. Nie przewidywała go również Konstytucja URL, która została uchwalona 29 IV 1918 r. w ostatnim dniu funkcjonowania Ukraińskiej Centralnej Rady. Poza tym nie jest znany żaden akt polityczno-prawny dokonany przez M. Hruszewskiego jako prezydenta URL. Oczywiste jest natomiast, że M. Hruszewski był tylko „prezydentem” (przewodniczącym) Ukraińskiej Centralnej Rady - parlamentu URL (posługiwał się nawet wizytówką w języku francuskim - President du Parlament [!] d'Ukraine). Był to najwyższy funkcjonariusz w URL w owym czasie. Jednak M. Hruszewski, będąc jeśli nie charyzmatycznym, to obdarzonym największym autorytetem przywódcą ruchu ukraińskiego tamtego czasu, formalnie nie był prezydentem URL. Zgodnie ze słowami M. Kowalewskiego M. Hruszewski pełnił najwyższa funkcje reprezentanta państwa. Właśnie to dało podstawy A. Żukowskiemu do nazywania M. Hruszewskiego pierwszym niekoronowanym prezydentem ukraińskiego pañstwa.

110 Kongres Pracy Ukrainy w 1919 r. opowiadał się za przygotowaniem ustawy o wyborach ogólnonarodowego parlamentu.

111 Закон про тимчасове Верховне Уиравління та порядок законодавства в Украӥнській Народній 
Ludowej"112. Te akty normatywno-prawne przekazały funkcje ustawodawcze oraz kontrolę nad rządem URL Państwowej Radzie Ludowej (nowemu parlamentowi). Jednak do chwili zwołania Państwowej Rady Ludowej jej kompetencje zostały powierzone Radzie Ministrów Ludowych, zaś Przewodniczący Dyrektoriatu (był nim wówczas S. Petlura) pełnił (indywidualnie) obowiązki głowy państwa. Przewodniczącego Dyrektoriatu, w przypadku braku możliwości pełnienia przezeń obowiązków, zastępowało kolegium, a w razie niemożności jego zwołania - Przewodniczący Rady Ministrów Ludowych.

Podobny model republikanizmu (parlamentarny system rządów) i podobne znaczenie stanowiska prezydenta zostały przewidziane w niepodległej od 15 do 18 marca 1939 r. Karpato-Ukrainie. Tak np. konstytucyjne ustawy tego nieuznanego państwa wprowadziły następujące regulacje: prezydent jako głowa państwa wybierany jest przez Sejm (parlament Karpato-Ukrainy); na czele władzy wykonawczej stoi premier, którego również wybiera Sejm; premier i prezydent są politycznie odpowiedzialni przed parlamentem. Określono także prawo rządu do wydawania za zgodą prezydenta tymczasowych rozporządzeń z mocą prawa. Nie mogły one zawierać zmian ustaw konstytucyjnych i powinny były być wniesione w postaci projektów ustaw na najbliższe obrady Sejmu, gdyż w innym przypadku traciły moc prawną. Pierwszym i ostatnim prezydentem Karpato-Ukrainy był A. Wołoszyn. Oznacza to, że myśl polityczno-prawna i praktyka polityczna Ukraińskiej Republiki Ludowej i Karpato-Ukrainy zmierzała w kierunku wprowadzania modelu parlamentarnego republikanizmu (parlamentarnego systemu rządów), a co za tym idzie do stanowiska - obieranego przez parlament na określony czas - prezydenta wyłącznie jako głowy państwa.

Z drugiej strony w Zachodnioukraińskiej Republice Ludowej (ZURL) w różnych okresach zaaprobowano odmienne projekty i koncepcje konstytucji, które zostały zaproponowane przez S. Dnistriańskiego, posła do austriackiego parlamentu i profesora Uniwersytetu Lwowskiego. Pierwszy projekt tego uczonego, który został przygotowany pod koniec października 1918 r. i nosił nazwę Ustrój Państwa Galicyjskiego ${ }^{113}$, w znacznej mierze odwoływał się do instytucjonalnej praktyki URL i przewidywał stworzenie państwa z parlamentarnym systemem rządów, w którym władza ustawodawcza powinna należeć do Ukraińskiej Rady Narodowej (Ludowej) (którą wybrano 18 października 1918 r.), natomiast władza wykonawcza do Rządu (Zarządu Ludowego czy Sekretariatu Państwowego), który został sformowany i był odpowiedzialny przed parlamentem (pierwszy rząd, z K. Łewyckim na czele, został utworzony 9 listopada 1918 r.). Ukraińska Rada Narodowa była traktowana jako tymczasowy parlament, który na mocy wyborów przeprowadzonych $\mathrm{w}$ oparciu o system proporcjonalny (,z proporcjonalną reprezentacją dla mniejszości narodowych”) powinien być zastąpiony przez funkcjonujący stale Sejm Ludowy. Zostało to zatwierdzone w przyjętej 13 listopada 1918 r. „Tymcza-

Республіці від 12 листопада 1920 р., [w:] Конститущійні акти України. 1917-1920. Невідомі конститущї України, Київ 1992.

112 Закон иро Державну Народну Раду Української Народної Республіки від 12 листопада 1920 року, „Вісник Аержавних Законів для всіх земель Української Народної Респубкіки” 1920, 19 XI, Vol. 2.

113 П. Стецюк, Станіслав Аністрянський..., s. 59-60. 
sowej Ustawie Zasadniczej o państwowej niepodległości ziem ukraińskich byłej monarchii austro-węgierskiej"114, w której w żaden sposób nie wspomniano o stanowisku prezydenta ZURL. Dopiero po jakimś czasie (4 stycznia 1919 r.) tekst Tymczasowej Konstytucji ZURL uzupełniono grupą, jak to nazywa B. Tyszczyk, tzw. „ustaw konstytucyjnych”"15, np. „O Wydziale Ukraińskiej Rady Narodowej” - swoistej instytucji kolegialnej głowy państwa w składzie: Prezydent Ukraińskiej Rady Narodowej i dziewięciu osób (łącznie dziesięciu członków) ${ }^{116}$. Kompetencje Wydziału określono w sposób następujący: wyznaczanie i mianowanie członków rządu, przedterminowe wstrzymywanie kompetencji członków rządu, przeprowadzanie amnestii i ułaskawienia/abolicji, mianowanie kierowników lokalnych władz publicznych, publikowanie praw ZURL. Szczególną (zwłaszcza podczas głosowań) siłę w Wydziale posiadał Prezydent, którego głos był decydujący podczas podejmowania konkretnych decyzji przez ten organ władzy państwowej - zwłaszcza wtedy, kiedy w czasie głosowania (koniecznie w obecności nie mniej niż sześciu członków Wydziału) głosy członków Wydziału rozdzielały się po równo. Argumentowano również, że Wydział Ukraińskiej Rady Narodowej wybierany jest na czas sprawowania władzy przez Ukraińską Radę Narodową i funkcjonuje do sformowania nowego Wydziału nowej Ukraińskiej Rady Narodowej. Faktycznie dyskusja dotyczyła instytucji kolegialnej prezydentury w warunkach parlamentarnego systemu rządów republikańskich (w rodzaju Dyrektoriatu w URL).

$\mathrm{Na}$ czele pierwszej i ostatniej instytucji kolegialnej prezydentury stanął J. Petruszewycz, który w latach 1918-1923 był prezydentem (przewodniczącym-marszałkiem) Ukraińskiej Rady Narodowej, najpierw w okresie od listopada 1918 r. do stycznia 1919 r. w granicach terytorium ZURL (do Aktu Zjednoczenia URL i ZURL), a w latach 1919-1923 (po podpisaniu i wypowiedzeniu Aktu Zjednoczenia URL i ZURL) w granicach terytorium Zachodniego Obwodu URL oraz w formacie funkcjonowania ZURL na uchodźstwie ${ }^{117}$. Będąc przewodniczącym najwyższych władz publicznych ZURL (Ukraińskiej Rady Narodowej i jej Wydziału), J. Petruszewycz z początku pełnił tylko funkcje przedstawicielskie, nie mając realnych kompetencji do prowadzenia własnej polityki wewnętrznej i zewnętrznej państwa. Co więcej, w styczniu 1919 r. (po podpisaniu Aktu Zjednoczenia URL i ZURL) J. Petruszewycz jako przewodniczący Zachodniego Obwodu URL wszedł w skład Dyrektoriatu URL - innego organu władzy państwowej, który wykonywał funkcje kolegialnego szefa państwa - co osłabiło jego uprawnienia jako kierownika instytucji kolegialnej głowy państwa w ZURL.

114 Тимчасовий основний закон про державну самостійність українських земель бувшої АвстроУгорської монархії, ухвалений Українською Національною Радою на засіданні 13 листопада 1918 р., [w:] М. Аозинський, Галичина в рр. 1918-1920, Прага 1922, s. 45-46; В. Костів, Конституційні акти відновленої української держави 1917-1919 років і іхня політично-державна якість, Торонто 1964.

115 Б. Тищик, Конституційне законодавство Західно-Украйнської народні Республіки, „Науковий Збірник Українського Вімьного Університету” 1995, Vol. 17, s. 303-308.

116 Закон про Виділ Української Ради 4 січня 1919 р., [w:] М. Аозинський, Галичина в рр. 1918-1920, Прага 1922, s. 62-63.

117 М. Аитвин, К. Науменко, Iсторія ЗУНР, Аьвів 1995, s. 140. 
Sytuacja zmieniła się dopiero w czerwcu 1919 r., kiedy Ukraińska Rada Narodowa (ze względu na zagrożenie militarne ze strony Polski, a także wewnętrzne spory w kierownictwie URL) nadała J. Petruszewyczowi specjalne uprawnienia „Dyktatora" - najwyższego zwierzchnika wojskowo-politycznego na czas wojny - co oznaczało połączenie jego kompetencji jako głowy państwa i szefa rządu ZURL. Faktycznie (nawet mimo że J. Petruszewycz nie został wybrany na prezydenta w wyborach powszechnych) oczekiwano przejścia republikańskiej formy rządów od systemu parlamentarnego do prezydenckiego systemu rządzenia, czyli od traktowania prezydenta zaledwie jako głowy państwa do prezydenta pojmowanego jako głowa państwa i zwierzchnik władzy wykonawczej.

Podobne rozwiązanie przewidywał drugi projekt Konstytucji Zachodnioukrainskiej Republiki Ludowej S. Dnistriańskiego z 1920 r. ${ }^{118}$ Dokument ten okreslał ZURL jako republikę prezydencką, w której władzę ustawodawczą powinna reprezentować Izba Ludowa (parlament), zaś władza wykonawcza powinna się znaleźć w rękach Prezydenta Republiki (jako głowy państwa i przewodniczącego rządu - Rady Państwa). Obydwa organy władzy publicznej powinny być formowane w oparciu o jednoczesne wybory powszechne (odbywające się co cztery lata) ${ }^{119}$. Przewidywano, że do prezydenta będzie należało pełnienie następujących funkcji: kierowanie rządem; zwierzchnictwo nad siłami zbrojnymi państwa; nadawanie i odbieranie wojskowych tytułów i rang; mianowanie i zwalnianie członków Rady Państwa i Przewodniczącego Państwowego Wymiaru Sprawiedliwości, a także wykonywanie funkcji najwyższego zwierzchnika aparatu wewnętrznego i władzy sądowniczej w państwie; przysługiwało by mu również prawo do ułaskawiania itp. Przewidywano możliwość wysuwania przez parlament (dwiema trzecimi głosów) oskarżeń politycznych pod adresem prezydenta, a także wnoszenie przez parlament wniosku o jego odsunięcie od władzy.

Wszystko to oznacza, że w walce politycznej ziem ukraińskich o niepodległość, a co za tym idzie w międzyinstytucjonalnych relacjach politycznych i prawnych różnych ukraińskich tworów państwowych na początku i w pierwszej połowie XX w. wcielono w życie dwa modele stanowiska prezydenta: jeden - w warunkach parlamentarnego systemu rządów republikańskich - przewidywał stanowisko prezydenta jako głowy państwa, wybranej w parlamencie na określoną czasowo kadencję (w przypadku Ukraińskiej Republiki Ludowej, Karpato-Ukrainy i pierwszego okresu istnienia Zachodnioukraińskiej Republiki Ludowej); drugi - w warunkach prezydenckiego systemu rządów republikańskich - przewidywał stanowisko prezydenta jako szefa władzy wykonawczej i głowy państwa, wybranej w wyborach powszechnych na określoną czasowo kadencję (drugi okres istnienia Zachodnioukraińskiej Republiki Ludowej). Mimo że w myśli polityczno-prawnej i w praktyce przeważał wówczas model parlamentarnego republikanizmu ze stanowiskiem prezydenta jako głowy państwa, obieranego przez parlament, dwa zaaprobowane modele prezydentury (parlamentarny i pre-

118 П. Стерчо, Картапо-Українська Аержава. Ао історії визвольної боротьби карпатських українців y 1919-1939 роках, Аьвів 1994, s. 147-150.

119 М. Мацкевич, Конституційне законодавство в ЗУНР..., s. 255-261. 
zydencki) połączyła idea stanowiąca, że stanowisko prezydenta musi być postrzegane jako pewien czynnik stabilizacyjny i amortyzator pomiędzy przeciwdziałającymi siłami politycznymi w społeczeństwie, zwłaszcza jeśli znajdują się one w przejściowym stadium rozwoju.

Tabela 1. Historia instytucji prezydentury w politycznej historii Ukrainy

(na przykładzie niektórych ukraińskich tworów państwowych w latach 1918-1991)

\begin{tabular}{|c|c|c|c|c|c|c|}
\hline $\begin{array}{l}\text { Twór } \\
\text { pań- } \\
\text { stwowy }\end{array}$ & Prezydent & Czas kadencji & $\begin{array}{c}\text { Partia } \\
\text { polityczna }\end{array}$ & $\begin{array}{l}\text { Status } \\
\text { konstytu- } \\
\text { cyjny }\end{array}$ & $\begin{array}{l}\text { Typ prezy- } \\
\text { dentury }\end{array}$ & $\begin{array}{l}\text { System rządów/ } \\
\text { konstytucyjny } \\
\text { sposób wyboru }\end{array}$ \\
\hline \multirow{7}{*}{ URL } & $\begin{array}{l}\text { W. Wynny- } \\
\text { czenko }\end{array}$ & $\begin{array}{c}\text { 14 XII 1918- } \\
\text {-13 II } 1919\end{array}$ & USDRP & $\begin{array}{l}\text { Głowa } \\
\text { państwa }\end{array}$ & Kolegialna & $\begin{array}{c}\text { Parlamentaryzm/ } \\
\text { Parlamentarny }\end{array}$ \\
\hline & S. Petlura & $\begin{array}{l}9 \mathrm{~V} 1919- \\
-25 \mathrm{~V} 1926\end{array}$ & USDRP & $\begin{array}{l}\text { Głowa } \\
\text { państwa }\end{array}$ & $\begin{array}{l}\text { Kolegialna/ } \\
\text { Indywi- } \\
\text { dualna }\end{array}$ & $\begin{array}{c}\text { Parlamentaryzm/ } \\
\text { Parlamentarny }\end{array}$ \\
\hline & A. Liwyćkyj I & $\begin{array}{l}25 \text { V } 1926- \\
-10 \text { VI } 1948\end{array}$ & USDRP & $\begin{array}{l}\text { Głowa } \\
\text { państwa }\end{array}$ & $\begin{array}{l}\text { Indywi- } \\
\text { dualna }\end{array}$ & $\begin{array}{c}\text { Parlamentaryzm/ } \\
\text { Parlamentarny }\end{array}$ \\
\hline & A. Liwyćkyj II & $\begin{array}{c}10 \text { VI } 1948- \\
-17 \text { I } 1954\end{array}$ & USDRP & $\begin{array}{l}\text { Głowa } \\
\text { państwa }\end{array}$ & $\begin{array}{l}\text { Indywi- } \\
\text { dualna }\end{array}$ & $\begin{array}{c}\text { Parlamentaryzm/ } \\
\text { Parlamentarny }\end{array}$ \\
\hline & S. Wytwyćkyj & $\begin{array}{l}17 \text { I 1954- } \\
-9 \text { X } 1965\end{array}$ & Bezpartyjny & $\begin{array}{l}\text { Głowa } \\
\text { państwa }\end{array}$ & $\begin{array}{l}\text { Indywi- } \\
\text { dualna }\end{array}$ & $\begin{array}{c}\text { Parlamentaryzm/ } \\
\text { Parlamentarny }\end{array}$ \\
\hline & M. Liwyćkyj & $\begin{array}{l}22 \text { III } 1967- \\
-8 \text { XII } 1989\end{array}$ & Bezpartyjny & $\begin{array}{l}\text { Głowa } \\
\text { państwa }\end{array}$ & $\begin{array}{l}\text { Indywi- } \\
\text { dualna }\end{array}$ & $\begin{array}{c}\text { Parlamentaryzm/ } \\
\text { Parlamentarny }\end{array}$ \\
\hline & M. Pławiuk & $\begin{array}{l}8 \text { XII 1989- } \\
-22 \text { VIII } 1992\end{array}$ & Bezpartyjny & $\begin{array}{l}\text { Głowa } \\
\text { państwa }\end{array}$ & $\begin{array}{l}\text { Indywi- } \\
\text { dualna }\end{array}$ & $\begin{array}{c}\text { Parlamentaryzm/ } \\
\text { Parlamentarny }\end{array}$ \\
\hline \multirow[b]{2}{*}{ ZURL } & \multirow[b]{2}{*}{ J. Petruszewycz } & $\begin{array}{l}4 \text { I } 1919- \\
-22 \text { I } 1919\end{array}$ & \multirow[b]{2}{*}{ UNDP } & $\begin{array}{l}\text { Głowa } \\
\text { państwa }\end{array}$ & Kolegialna & $\begin{array}{c}\text { Parlamentaryzm/ } \\
\text { Parlamentarny }\end{array}$ \\
\hline & & $\begin{array}{l}19 \text { VI 1919- } \\
-15 \text { III } 1923\end{array}$ & & $\begin{array}{c}\text { Głowa } \\
\text { państwa } \\
\text { i szef wła- } \\
\text { dzy wyko- } \\
\text { nawczej }\end{array}$ & $\begin{array}{l}\text { Indywi- } \\
\text { dualna }\end{array}$ & $\begin{array}{l}\text { Prezydencki/ } \\
\text { Ogólnonarodowy }\end{array}$ \\
\hline $\begin{array}{l}\text { Karpato- } \\
\text {-Ukraina }\end{array}$ & A. Wołoszyn & $\begin{array}{l}15 \text { III 1939- } \\
\text {-18 III } 1939\end{array}$ & NChP & $\begin{array}{l}\text { Głowa } \\
\text { państwa }\end{array}$ & $\begin{array}{l}\text { Indywi- } \\
\text { dualna }\end{array}$ & $\begin{array}{l}\text { Parlamentaryzm/ } \\
\text { Parlamentarny }\end{array}$ \\
\hline
\end{tabular}

URL - Ukraińska Republika Ludowa; ZURL - Zachodnioukraińska Republika Ludowa; USDRP Ukraińska Socjaldemokratyczna Partia Robotnicza; UNDP - Ukraińska Partia Narodowo-Demokratyczna; LChP - Partia Ludowo-Chrześcijańska

Późniejszy rozwój (a dokładniej rzecz biorąc - brak) instytucji prezydentury na Ukrainie po walkach narodowyzwoleńczych początku XX w. został podyktowany tym, że kraj ten wchodził przeważnie w skład Związku Sowieckiego, którego systemu politycznego nie można zestawiać z parlamentarnym albo prezydenckim systemem rządów 
republikańskich ${ }^{120}$. Mimo że w sowieckim procesie polityczno-prawnym miały miejsce próby wprowadzenia stanowiska prezydenta (w 1936, 1964 i 1988 r.), idea ta nie została zrozumiana i poparta przez ogół aparatu partyjnego ani przez najwyższe szczeble władzy. Było to spowodowane tym, że według klasycznych modeli realizacji władzy instytucja prezydentury jest nierozerwalnie związana z podziałem władz. Tymczasem oficjalna państwowa ideologia okresu sowieckiego negowała podział władz jako sposób organizacji systemu politycznego ${ }^{121}$, gdyż uważała go za wartość obcą socjalistycznemu modelowi rozwoju. Taką ideę obserwujemy jeszcze w czasach J. Stalina, który na propozycję wprowadzenia instytucji prezydentury do projektu Konstytucji ZSRS w 1936 r. zauważyl, że zgodnie z systemem Konstytucji w ZSRS nie powinno być wybieranego przez ogół ludności jednoosobowego prezydenta będącego na równi z Radą Najwyższą i zdolnego przeciwstawić się Radzie Najwyższej; że prezydent jest w ZSRS kolegialny i jest nim Prezydium Rady Najwyższej ${ }^{122}$.

Sytuacja zmieniła się diametralnie w marcu 1990 r., kiedy III Nadzwyczajny Zjazd Deputowanych Ludowych uchwalił Ustawę „O wprowadzeniu stanowiska Prezydenta ZSRS i wniesieniu zmian i uzupełnień do Konstytucji (Ustawy Zasadniczej) ZSRS"123. Zwrócenie się ku idei instytucji prezydentury w ZSRS zostało podyktowane dramatycznymi wydarzeniami tego czasu, kryzysem sowieckiego federalizmu, który wystąpił po ogłoszeniu kursu na społeczno-ekonomiczną i polityczną "przebudowę" i demokratyzację kraju ${ }^{124}$. Wybory pierwszego prezydenta ZSRS odbyły się bezpośrednio w trakcie Zjazdu Deputowanych Ludowych (najwyższego organu władzy państwowej w ZSRS), chociaż nadal przewidywano przeprowadzenie bezpośrednich powszechnych wyborów prezydenckich ${ }^{125}$. Ówczesny przewodniczący Rady Najwyższej ZSRS (dwuizbowego parlamentu) M. Gorbaczow został wybrany na pierwszego i ostatniego prezydenta Związku Sowieckiego ${ }^{126}$. Jednakże idea instytucji prezydentury została poparta przez większość ludności ZSRS, a zwłaszcza jej części zamieszkującej Ukraińską SRS, co stało się wkrótce przyczyną wprowadzenia analogicznej instytucji we wszystkich państwach posowieckich. Co więcej, podczas tworzenia stanowiska prezydenta na

120 Niemniej jednak Związek Sowiecki, a w szczególności Ukraińska SRR pod względem systemu rządów państwowych (zwłaszcza ze względu na idę̨ wszechwładzy rad, chociaż także krytycznego stosunku do teorii polityczno-prawnej) przypominały republiki parlamentarne.

121 А. КуАряченко, Институт президентства в Украине: реалии конституиионно-правового статуса, „Государство и право” 1998, Vol. 3, s. 100.

122 И. Сталин, Вопросы ленинизма, Москва 1945, s. 517.

123 I. Стрижова, Інститут президентства на пострадянському просторі, „Гікея” 2011, Vol. 49; Про заснування поста Президента СРСР і внесення змін та доповнень до Конституції (Основного Закону) СРСР: Закон Союзу Радлнських Соціалістичних Республік № 1360-I від 14.03.90, [online] http://zakon4.rada.gov.ua/laws/show/v1360400-90.

124 С. Паречина, Институт президентства: история и современность, red. Е. Матусевич, Минск 2003.

125 Конституиия (Основной Закон) Союза Советских Сочиалистических Республик, „Свод законов CCCP" 1990, Vol. 3, s. 7.

126 Ведомости Свезда народнъх депутатов СССР и Верховного Совета СССР, 1990, Vol. 7; В. Горбатюк, Інститут президентства в Україні..., s. 326. 
Ukrainie (formalnie w Ukraińskiej SRS), co miało miejsce 5 lipca $1991 \mathrm{r} \cdot{ }^{127}$ (w wyniku wprowadzenia zmian do Konstytucji Ukraińskiej SRS pochodzącej z 1978 r. ${ }^{128}$ ), podjęto próbę uwzględnienia zarówno ogólnozwiązkowych norm i doświadczeń, jak i ustawodawstwa zagranicznego ${ }^{129}$.

Po rozpadzie Związku Sowieckiego większość nowo powstałych republik, w tym również Ukraina, postanowiła zaaprobować zasadę podziału władz na wykonawczą, ustawodawczą i sądowniczą, a także mechanizm zapewnienia wzajemnego powstrzymywania i przeciwwagi pomiędzy strukturami władzy ${ }^{130}$. Zasada ta stała się systemotwórczym czynnikiem istnienia państwa i miała sprzyjać elastycznej wzajemnej kontroli i współdziałaniu najwyższych organów jako części zintegrowanej władzy państwowej. W wyniku tego instytucja prezydentury i jej funkcjonalne wcielenie w perspektywie zapewnienia współdziałania struktur władzy w ramach realizacji zasady podziału władz na Ukrainie na obecnym etapie rozwoju instytucjonalnego nabrało bardzo dużego znaczenia polityczno-prawnego. Oprócz tego, oczywiście, że idea instytucji prezydentury na Ukrainie nie została narzucona z zewnątrz, lecz była wynikiem procesów historycznych, które dojrzały wewnątrz społeczeństwa, w podejściu intelektualnym elity politycznej - z nastawieniem na konieczność reformowania władzy państwowej oraz systemu politycznego i społeczno-ekonomicznego.

W kształtowaniu się instytucji prezydentury na Ukrainie (formalnie jeszcze w składzie ZSRS) znaczącą rolę odegrała Deklaracja o państwowej suwerenności Ukrainy ${ }^{131}$ z 16 lipca 1990 r., która głosiła, że władza w państwie powinna być realizowana na zasadzie jej podziału na ustawodawczą, wykonawczą i sądownicząą2. Wiosną 1991 r. w Radzie Najwyższej Ukraińskiej SRS prowadzone były prace zmierzające do przygotowania projektów ustaw, koniecznych do wprowadzenia stanowiska Prezydenta Ukrainy. Zagorzali zwolennicy niepodlegtości Ukrainy popierali ideę wprowadzenia instytucji silnego prezydenta jako głowy państwa i szefa władzy wykonawczej (modele systemu prezydenckiego), mieli oni świadomość tego, że władza prezydencka jest zdolna do stosunkowo szybkiego zlikwidowania radzieckiego systemu politycznego. Natomiast przeciwnicy niepodlegtości Ukrainy w osobach konserwatywnych deputowanych komu-

127 Про заснування поста Президента Украйнської РСР і внесення змін та доповнень до Конституиії (Основного Закону) Української РСР: Закон Украйнської Радянської Соиіалістичної Республіки від 5 мипня 1991 р., „Відомості Верховної Ради УРСР (ВВР)” 1991, Vol. 33, s. 445; Про Президента Української РСР: Закон Української Радянської Сочіалістичної Республіки від 5 мипня 1991 р., „Відомості Верховної Ради УРСР (ВВР)” 1991, Vol. 33, s. 446; Про вибори Президента Української РСР: Постанова Верховної Ради Української РСР від 5 липня 1991 р., „ВіАомості Верховної Ради УРСР (ВВР)" 1991, Vol. 33, s. 450.

128 Конституиія (Основний Закон) України. 20 квітня 1978 р. (із змінами і доповненнями, внесеними станом на 21 вересня 1994 р.), Київ 1994.

129 И. Тодика, В. Яворский, Президент Украинью.., s. 72.

130 Конституиія України. Прийнята на п'ятій сесї̈ Верховної Ради України 28 червня 1996 р., Київ 1997.

131 Аекларація про державний суверенітет Украйни від 16 липня 1990 р., „Відомості Верховної Ради УРСР (ВВР)" 1990, Vol. 31, s. 429.

132 Конституційне право Украӥни, red. В. Погорілко, Київ 1999. 
nistycznych nalegali na wprowadzenie instytucji słabego prezydenta jako głowy państwa, który byłby wybierany w parlamencie (modele parlamentaryzmu), rozumieli oni, że władza prezydencka może zostać podporządkowana Biuru Politycznemu Komunistycznej Partii Ukrainy. W rezultacie teoretyczną podstawą kształtowania instytucji prezydentury na Ukrainie na początku lat 90. XX w. stała się Koncepcja nowej konstytucji Ukrainy, przyjęta 19 czerwca 1991 r. przez Radę Najwyższą Ukraińskiej SRS ${ }^{133}$. Nieco później, 25 czerwca 1991 r., Rada Najwyższa przyjęłą uchwałę „O wyborach Prezydenta Ukraińskiej SRS”134 i określiła, że powszechne wybory Prezydenta Ukraińskiej SRS powinny się odbyć w $1991 \mathrm{r}$.

Zgodnie z rozdziałem 12-1 Konstytucji Ukraińskiej SRR z 1978 r. z poprawkami i uzupełnieniami, prezydent z początku (poczynając od 5 lipca 1991 r.) określany był jako najwyższy funkcjonariusz i zwierzchnik władzy wykonawczej w państwie, a z czasem (od 14 lutego 1992 r.), zgodnie z art. 114-1 Konstytucji Ukraińskiej SRS z 1978 r., jako głowa państwa i zwierzchnik władzy wykonawczej na Ukrainie. Jednakże - jak wynika ze słów A. Hulijewa ${ }^{135}$ - na tym etapie regulacji konstytucyjno-prawnych instytucja prezydenta nie była w sposób wszechstronny, jednolity i konsekwentny uzasadniona (podobnie zresztą jak i republikański system rządzenia państwem na Ukrainie we wpomnianym czasie $)^{136}$. Świadczą o tym efekty prezydentury L. Krawczuka, który został wybrany 1 grudnia 1991 r. Z początku pierwszy prezydent postsowieckiej

133 Про Конщепцію нової Конституції Украӥни: Постанова Верховної Ради Украйнської РСР від 19 червня 1991 р., „Відомості Верховної Ради УРСР (ВВР)” 1991, Vol. 35, s. 466; Конституиія незалежної України, Vol. 1, Київ 1995, s. 65-77.

Про вибори Президента Української РСР..., s. 450.

135 А. Гулиев, Институт президентства..., s. 154.

136 Co więcej, w ogóle system podziału władz na Ukrainie po wprowadzeniu instytucji prezydenta 5 VII 1991 r. stanowił przypadek „niezrozumiałej kombinacji”, ponieważ gałęzie władzy nie miały określonego oficjalnego statusu, struktury i pojęcia o mechanizmach stworzenia efektywnego systemu rządów republikańskich. Na przykład parlament został obdarzony najwyższymi uprawnieniami ustawowodawczymi i częściową władzą nad rządem, a prezydentowi przyznano prawo do określania struktury rządu i przydzielono znaczącą rolę w ustawodawstwie. Faktycznie na Ukrainie we wspomnianym okresie funkcjonował półprezydencki prezydencko-parlamentarny (jednocześnie prezydenckopodobny, gdyż prezydent nie mógł rozwiązywać parlamentu, i parlamencko-dominujący) system rządów (chociaż koncepcje kierunków rozwoju systemu politycznego na Ukrainie przewidywały prezydencki system rządów). Przede wszystkim przejawiało się to w tym, że: prezydent i parlament brali udział w formowaniu i dymisjonowaniu rządu czy też poszczególnych jego członków (przy czym parlament mógł dymisjonować wszystkich członków gabinetu, a prezydent mógł mianować bez zgody parlamentu większość członków gabinetu - faktycznie oznaczało to, że podczas formowania rządu był on zależny od prezydenta, zaś w trakcie swej działalności - od parlamentu); prezydent i premier mieli uprawnienia do działalności ustawodawczej; parlament miał ograniczone uprawnienia w zakresie kierowania państwem; parlament w znacznej mierze „zacienial” funkcje organów władzy sądowniczej. Dokładnie zob.: D. Boban, „Minimalist” Concepts of Semi-presidentialism: Are Ukraine and Slovenia Semi-presidential States?, „Politička misao” 2007, Vol. 44, nr 5, s. 155-177; K. Matsuzato, Semipresidentialism in Ukraine: Institutionalist Centrism in Rampant Clan Politics, „Democratization” 2005, Vol. 13, nr 1, s. 453-474; O. Protsyk, Constitutional Politics..., s. 23-31; T. Jung-Hsiang, Sub-types of Semi-presidentialism and Political Deadlock, „French Politics” 2008, Vol. 6, nr 1, s. 63-84, [online] http://dx.doi.org/ 10.1057/palgrave.fp.8200140. 
Ukrainy był traktowany jako najwyższy funkcjonariusz w państwie. Jednakże z czasem, w okresie od września 1993 do lipca 1994 r., kiedy obowiązywał dekret prezydenta „O kierowaniu Radą Ministrów Ukrainy” ${ }^{137}$, prezydent łączył jednocześnie kompetencje głowy państwa i zwierzchnika władzy wykonawczej. Przejawiało się to przede wszystkim w tym, że prezydent brał udział w formowaniu i dymisjonowaniu rządu lub poszczególnych jego członków: mianował premiera, ministrów obrony, spraw zagranicznych i spraw wewnętrznych pod warunkiem zatwierdzenia ich przez parlament, a także - już bez konieczności zatwierdzenia ich przez parlament - innych ministrów (obowiązywała jednak zasada bezpośredniej podległości oraz kolektywnej i indywidualnej odpowiedzialności rządu przed prezydentem/parlamentem). Prócz tego prezydent dysponował pewnymi uprawnieniami w działalności ustawodawczej: nie miał prawa weta wobec ustaw przyjętych przez parlament, miał jednak prawo inicjatywy ustawodawczej; mógł wydawać dekrety (do 1992 r. z mocą ustawy), jeśli dotyczyły one sfery reform ekonomicznych, pod warunkiem że przedmiot dekretów nie był regulowany specjalnymi ustawami Ukrainy; był odpowiedzialny za przedłożenie do rozpatrzenia przez parlament corocznego projektu budżetu Ukrainy. Jednocześnie cechą charakterystyczną tego okresu był fakt, że legitymizacja prezydenta wybranego w wyborach powszechnych w grudniu 1991 r. (formalnie w niepodległej Ukrainie) była wyższa niż legitymizacja wybranej w marcu 1990 r. (formalnie w składzie Ukraińskiej SRS) Rady Najwyższej ${ }^{138}$.

Poczynając od września 1994 r. (po przyjęciu kolejnych poprawek do Konstytucji Ukraińskiej SRS z 1978 r.), Prezydent Ukrainy (został nim wybrany w przedterminowych wyborach 10 lipca 1994 r. L. Kuczma) jako głowa państwa i zwierzchnik władzy wykonawczej w państwie otrzymał uprawnienia do sprawowania funkcji gwaranta ochrony praw i swobód obywateli, suwerenności, przestrzegania Konstytucji i praw Ukrainy, reprezentowania kraju w relacjach międzynarodowych, zastosowania środków dla zapewnienia zdolności do obrony, bezpieczeństwa narodowego i integralności terytorialnej Ukrainy, sprawowanie funkcji zarządzających i wytyczanie kierunków działalności Rady Ministrów Ukrainy, stania na czele systemu lokalnych organów państwowej władzy wykonawczej, zapewniania ich współdziałania z Radą Najwyższą Ukrainy. W praktyce polityczne (wykonawczo-zarządcze) kompetencje prezydenta (w kontekście formowania, kierowania i przedterminowego wstrzymania kompetencji rządu) zostały wzmocnione przez znaczącą fragmentaryzację i frakcjonalizację pierwszej ukształtowanej w historii niepodległej Ukrainy Rady Najwyższej (ponieważ

137 Dekret prezydenta „O kierownictwie Rady Ministrów Ukrainy” ustalał, że prezydent miał sprawować bezpośrednie kierownictwo nad Radą Ministrów Ukrainy jako najwyższym organem władzy wykonawczej. Dokładnie zob.: Про керівництво Кабінетом Міністрів України: Указ Президента України від 27 вересня 1993 р., „Голос України” 1993, 28 III.

$138 \mathrm{Z}$ uwagi na spory społeczno-ekonomiczne na Ukrainie, a także międzyinstytucjonalne konflikty w systemie władz państwa mogło to nawet stać się przyczyną planowanego na 26 IX 1993 r. referendum konsultacyjnego na temat zaufania/nieufności do prezydenta i parlamentu. Jednak wyjściem z sytuacji (zamiast przeprowadzenia referendum) stały się przedterminowe wybory parlamentarne i prezydenckie, które odbyły się odpowiednio 27 III i 26 VI (druga tura 10 VII) 1994 r. 
ponad połowę składu parlamentu stanowili deputowani bezpartyjni - sytuacja częściowo się rozwiązała przez tworzenie różnych frakcji deputowanych, które ciągle się reformatowały ze względu na polityczną celowość i osobiste korzyści deputowanych). Wynikiem tego było zaaprobowanie i ustalenie praktyki formowania niepartyjnych gabinetów rządowych, którymi faktycznie, poprzez osobę premiera, kierował prezydent Ukrainy.

Jeszcze większe uprawnienia Prezydent Ukrainy (również jako głowa państwa i zwierzchnik władzy wykonawczej) otrzymał 8 czerwca 1995 r., kiedy przyjęto tymczasową (na okres jednego roku) „Umowę konstytucyjną między Radą Najwyższą Ukrainy i Prezydentem Ukrainy” o głównych zasadach organizacji i funkcjonowania władzy państwowej oraz samorządu lokalnego na Ukrainie na czas do momentu przyjęcia nowej Konstytucji Ukrainy ${ }^{139}$. Ta tzw. ustawa „O władzy” oznaczała kres sowieckiego (nawet z poprawkami) systemu władzy, przewidywała zmianę struktury wzajemnych relacji między ustawodawczymi i wykonawczymi strukturami władzy. Między innymi wykreślono prawo parlamentu do zatwierdzania rządu i wpływania na mianowanie poszczególnych członków gabinetu, a także ograniczono kompetencje parlamentu w kwestii wyrażenia wotum nieufności wobec rządu. Prezydent otrzymał natomiast prawo do niezależnego/jednostronnego mianowania premiera i formowania gabinetu, a także zwalniania członków rządu bez zgody parlamentu. W rezultacie wzmocniono władzę prezydencką nad gabinetami rządowymi i ustalono bardziej bezpośrednią podległość rządu wobec prezydenta (właśnie dlatego niepartyjne rządy, które zostały sformowane w czasie obowiązywania Umowy konstytucyjnej, należy określać jako „prezydenckie” lub „sformowane przez prezydenta”). Tym samym formalnie po raz pierwszy i jak dotychczas po raz ostatni w historii posowieckiej Ukrainy został implementowany prezydencki system rządów republikańskich w państwie ${ }^{140}$.

139 Конститущійний договір між Верховною Радою України та Президентом України про основні засади організаиії та функиіонування державної влади і місиевого самоврядування в Украйні на період до прийняття нової Конституиії України: від 8 червня 1995 р., „Відомості Верховної Ради України (ВВP)" 1995, Vol. 18, s. 133; Конституція незалежної України, Vol. 1, Київ 1995, s. 331.

140 Wśród cech ówczesnego prezydencjalizmu na Ukrainie należy wyróżnić następujące: 1) formowanie i kolektywna odpowiedzialność rządu wyłącznie przed wybranym w wyborach powszechnych prezydentem jakogłową państwa i zwierzchnikiem władzy wykonawczej;2) brak możliwości wzajemnej dymisji prezydenta i parlamentu; 3) obdarzenie prezydenta prawem inicjatywy ustawodawczej, weta ustawodawczego, wydawania dekretów w sferze gospodarki, zwoływania ogólnonarodowego referendum na temat wprowadzenia zmian do Konstytucji; 4) istnienie stanowiska premiera (co nie jest typowe dla klasycznego prezydencjalizmu), odpowiedzialnego przed prezydentem, lecz bez prawa wydawania dekretów z mocą ustawy. Takie cechy przeważnie odpowiadają ustalonemu w nauce politycznej podejściu do prezydencjalizmu. Dokładnie zob.: M. Duverger, A New Political System Model: Semi-Presidential Government, „European Journal of Political Research” 1980, Vol. 8, nr 2, s. 165-187, [online] http://dx.doi.org/10.1111/j.1475-6765.1980.tb00569.x; R. Elgie, The Classification of Democratic Regime Type: Conceptual Ambiguity and Contestable Assumptions, „European Journal of Political Research” 1998, Vol. 33, nr 2, s. 219-238, [online] http://dx.doi.org/10.1111/1475-6765.00381; A. Krouwel, Measuring Presidentialism and Parliamentarism: An Application to Central and East European Countries, „Acta Politica” 2003, Vol. 38, nr 4, s. 333-364, 
Niejednoznaczny, niezupełnie kompleksowy i bardzo trudny okazał się także proces przyjęcia nowej Konstytucji Ukrainy (co dokonało się 28 czerwca $1996 \mathrm{r}^{141}$ - praktycznie najpóźniej wśród europejskich posowieckich krajów regionu). Przedmiotem szczególnych sporów i debat stała się instytucja prezydentury w płaszczyźnie perspektyw na wprowadzenie nowego modelu systemu politycznego. Rzecz w tym, że w latach 1991-1996 zaproponowano szereg projektów przyszłej Konstytucji Ukrainy, które rozmaicie opisywały miejsce i rolę prezydenta w systemie władzy państwowej. Jak wspomniano powyżej, jeszcze 19 czerwca 1991 r. została przyjęta koncepcja nowej Konstytucji Ukrainy, w której akcent położono na wprowadzenie republiki prezydenckiej, a co za tym idzie instytucji prezydenta jako najwyższego funkcjonariusza w państwie i zwierzchnika władzy wykonawczej ${ }^{142}$. Podobny projekt Konstytucji Ukrainy z 1 lipca 1992 r. proponował, by w stanowisku prezydenta zawrzeć funkcje politycznie odpowiedzialnej przed ukraińskim narodem głowy państwa i zwierzchnika władzy wykonawczej. Następny projekt Konstytucji Ukrainy z 26 października 1993 r. proponował skupienie w stanowisku prezydenta funkcji głowy państwa, politycznie odpowiedzialnej przed ukraińskim parlamentem. Na koniec wreszcie projekt Konstytucji Ukrainy z 24 lutego 1996 r. mocował do stanowiska prezydenta funkcje głowy państwa, politycznie odpowiedzialnej przed ukraińskim narodem ${ }^{143}$. Były także inne projekty Konstytucji Ukrainy, lecz te wymienione powyżej odzwierciedlały hipotetyczne

[online] http://dx.doi.org/10.1057/palgrave.ap.5500041; J.J. Linz, Presidential or Parliamentary Democracy: Does It Make a Difference?, [w:] The Failure of Presidential Democracy. Comparative Perspectives, red. tenże, A. Valenzuela, Baltimore 1994, s. 3-87; M. Shugart, J. Carey, Presidents and Assemblies. Constitutional Design and Electoral Dynamics, Cambridge-New York 1992; A. Siaroff, Comparative Presidencies: The Inadequacy of the Presidential, Semi-presidential and Parliamentary Distinction, „European Journal of Political Research” 2003, Vol. 42, nr 3, s. 287-312, [online] http:// dx.doi.org/10.1111/1475-6765.00084; K. Eaton, Review: Parliamentarism versus Presidentialism in the Policy Arena, "Comparative Politics” 2002, Vol. 32, nr 3, s. 355-376, [online] http://dx.doi. org/10.2307/422371; G. Sartori, Comparative Constitutional Engineering. An Inquiry into Structures, Incentives and Outcomes, London 1994; A. Stepan, C. Skach, Constitutional Frameworks and Democratic Consolidation. Parliamentarism versus Presidentialism, „World Politics” 1993, Vol. 46, nr 1, s. 1-22, [online] http://dx.doi.org/10.2307/2950664; О. Зазнаев, Классификачии президентской, парламентской і полупрезидентской систем, [w:] М. Фарукшин, Аинамика политических систем и международньх отномениях, Vol. 1, Казань 2006, s. 186-210.

141 Конституиіл України. Прийнята на п’ятій сесї...

${ }^{142}$ Z punktu widzenia politologii porównawczej przewidziana została nierównomierna synteza modelu prezydencjalizmu i półprezydencjalizmu. Rzecz w tym, że istniało rozwiązanie, zgodnie z którym skład Rady Ministrów (rządu) formowany był na mocy nominacji prezydenckiej i zatwierdzany przez Radę Najwyższą. Faktycznie system prezydencki był ograniczny przez fakt, że rząd (Rada Ministrów), kolektywnie odpowiedzialny przed prezydentem, zależał od parlamentu w kontekście swojego formowania, co ograniczało wyłączną wszechwwładzę prezydenta odnośnie do władzy wykonawczej władzy, właściwą klasycznym prezydenckim systemom rządów. Poza tym dla prezydenta nie przewidziano roli głowy państwa, ponieważ koncepcja nowej Konstytucji Ukrainy przewidywała, że prezydent ma być najwyższym funkcjonariuszem w państwie. Dokładnie zob.: Про Концепuiro нової Конституції України..., s. 466; А. Юзьков, Від Аекларації про державний суверенітет України до Конщепиї нової Конститущї України, [w:] Конституиія незалежної України, Vol. 1, red. С. Головатий, Київ 1995, s. 7-12.

143 В. Шаповац, Вищі органи сучасної держави. Порівняльний аналіз, Київ 1995, s. 11. 
warianty aprobacji i instytucjonalizacji stanowiska prezydenta w odpowiednio prezydenckich, parlamentarnych i półprezydenckich systemach rządów republikańskich ${ }^{144}$.

Ostatecznie wybrano projekt Konstytucji Ukrainy z 24 lutego 1996 r., w którym polityczny republikański system Ukrainy został 28 czerwca 1996 r. przekształcony z prezydenckiego w prezydencko-parlamentarny półprezydencki ${ }^{145}$. Odpowiednio do tego zostały zmienione kluczowe zasady, kompetencje, rola i miejsce prezydenta w systemie władzy państwowej. Przejawiło się to przede wszystkim w tym, że prezydent utracił formalnie właściwą mu przedtem funkcję zwierzchnika władzy wykonawczej, a zaczął być traktowany wyłącznie jako głowa państwa. Jednak prezydent (aczkolwiek wraz z parlamentem) zachowal centralną rolę w procesie formowania i przedterminowego wstrzymania kompetencji rządu. Przyjęta została m.in. norma, że prezydent mianuje premiera i kilku ministrów, jednakże nominacje te wymagały zatwierdzenia przez parlament (prócz tego prezydent i parlament mogli wyrażać kolektywne wotum nieufności wobec gabinetu rządowego). Również prezydentowi pozostawiono funkcje gwaranta państwowej suwerenności, integralności terytorialnej, przestrzegania Konstytucji, praw i swobód człowieka i obywatela na Ukrainie.

W praktyce wprowadzony model prezydencko-parlamentarnego systemu półprezydenckiego dość często utożsamiano z nieograniczonymi rządami prezydenckimi (na określenie takich systemów R. Elgie stosuje termin „prezydencjonalizowany system półprezydencki"). Rzecz w tym, że do lat 1996-2006, kiedy model ten został formalnie wykorzystany, prezydent (14 listopada 1999 r. powtórnie wybrano na to stanowisko L. Kuczmę, zaś 26 grudnia 2004 r. W. Juszczenkę) działał w systemie politycznym, dla którego permanentnie charakterystyczny był sfrakcjonalizowany - i dlatego też niezbyt wpływowy (przynajmniej z perspektywy faktycznego wpływu na rząd i proces prawodawczy) parlament (zwłaszcza w takim składzie, jaki był wynikiem wyborów parlamentarnych w 1998 i 2002 r. $)^{146}$. Poza tym instytucjonalna kontrowersyjność różnych projektów Konstytucji Ukrainy z lat 1991-1996 przyczyniła się do tego, że system rządów na Ukrainie nie osiągnął pełnego systemu półprezydenckiego ze skonsolidowanym mechanizmem kontroli, powstrzymywania i równowagi ${ }^{147}$. Dlatego też, z uwagi na faktyczny rozwój wydarzeń, prezydent skupił w swoich rękach nadmierne kompetencje: praktycznie jednoosobowo mianował i zwalniał ze stanowiska nie tylko premiera, ale także ministrów; w ogóle podporządkował sobie bezpośrednio ministrów stojących na czele resortów „siłowych"148. Oznacza to, że prezydent, który formalnie nie był nazywany zwierzchnikiem

144 В. Пігенко, Т. Пушак, Президентська, парламентська та змішана форма правління: досвід демократій Центрально-Східної Європи уконтексті становлення системи державного управління в Украйні, Програма сприяння парламенту. Програма розвитку законотворчої політики 2003. Конституція України. Прийнята на п'ятій сесії..

Т. Байхемьт, Р. Павленко, Президентські вибори і конститущійна реформа, [w:] Президентські вибори та Помаранчева револючія: вплив на трансформачійні прочеси в Украйні, Київ 2005, s. 49-84. ...канд. політ. наук: 23.00.02: захищ. 09.04.2010: затверджена 06.10.2010), ВиА. Аьвівський національний університет імені Івана Франка, ьвів 2010, s. 192-193. 
władzy wykonawczej, faktycznie kontrolował rząd. Co więcej, prezydent przeważnie w sposób nieformalny przejmował niektóre dodatkowe kompetencje. Na przykład jednoosobowo mianował i zwalniał ze stanowisk szefów miejscowych administracji ${ }^{149}$.

Równocześnie prezydent, powołując się na nieodpowiedzialność parlamentu ukraińskiego, podjął w 1999 r. próbę dalszego poszerzenia swoich uprawnień. Na mocy obowiązującej wówczas ustawy „O referendum ogólnoukraińskim i lokalnych referendach"150 prezydent z inicjatywy narodu zorganizował plebiscyt konsultacyjny. W jego kontekście pojawił się pomysł formowania „stałej większości parlamentarnej”. Rzecz $\mathrm{w}$ tym, że biorąc pod uwagę różnice we wpływach partii z poszczególnych regionów kraju, żadna z nich nie wprowadzała do parlamentu tylu deputowanych, aby móc samodzielnie stworzyć większość w parlamencie. Pomysł prezydenta polegał na stworzeniu sztucznej większości i kierowaniu nią przy użyciu groźby rozwiązania parlamentu w przypadku rozpadu większości na skutek braku poparcia dla kandydatury premiera i niezatwierdzenia w ciągu trzech miesięcy projektu budżetu państwa. W rezultacie (zwłaszcza po wyborach parlamentarnych w 2002 r.), prezydent dzięki konstrukcji większości parlamentarnej faktycznie wywierał presję na prace frakcjonalizowanego parlamentu i kierował działaniami rządu, przeważnie niepartyjnego i zorientowanego na prezydenta (zachowanie ministrów było często motywowane nie kolegialnym stanowiskiem rządu, lecz interesami prezydenta). Najciekawsze w tej konstrukcji było to, że prezydent nie ponosił formalnie odpowiedzialności za rezultaty działalności rządu i całej pionowej struktury władzy wykonawczej, nawet mimo że - zgodnie z postanowieniami Konstytucji Ukrainy z 1996 r. - był upoważniony do wydawania aktów ustawodawczych, rozporządzeń i szczególnych instrukcji (wskazówek), co wymagało od członków rządu podejmowania „pewnych czynności”. Oprócz tego prezydent, określając poszczególne projekty ustaw jako pilne, mógł w sposób decydujący wpływać na tryb ich rozpatrzenia w parlamencie. Prezydent miał również prawo weta: weto ustawodawcze pozwalało mu kontrolować stan spraw na płaszczyźnie ustawodawczej, natomiast weto wykonawcze pozwalało mu unieważniać uchwały rządu, akty ministerstw oraz innych organów władzy wykonawczej. Ogólnie rzecz biorąc, prawo do wydawania dekretów i rozporządzeń oraz zastosowania weta wobec aktów ustawodawczych i wykonawczych pozwalały prezydentowi dominować w trakcie podejmowania decyzji politycznych i w systemie politycznym jako takim ${ }^{151}$. Zgodnie z określeniem M. Shugarta i J. Careya pozwala to sklasyfikować półprezydencki system rządów na Ukrainie

O. Protsyk, Constitutional Politics..., s. 23-31; A. Wilson, Ukraine: Two Presidents and their Powers, [w:] Postcommunist presidents, red. R. Taras, Cambridge-New York 1997, s. 67-105; K. Wolczuk, The Moulding of Ukraine. The Constitutional Politics of State Formation, Budapest 2002.

149 R. Lindner, Die Ukraine zwischen Transformation und Selbstblockade. Wirtschaft, Politik und Parteien; regionale und ausländische Interessen vor den Parlamentswablen 1998, Ebenhausen Stiftung Wissenschaft und Politik 1998.

150 Про всеукраїнський та місиеві референдуми: Закон України від 3 миння 1991 р. № 1286-ХII, „Відомості Верховної Ради УРСР (ВВР)” 1991, Vol. 33, s. 443.

151 D. Boban, „Minimalist” Concepts..., s. 164; P. D’Anieri, Understanding Ukrainian Politics. Power, Politics, and Institutional Design, Armonk 2007. 
w latach 1996-2006 jako prezydenckopodobny prezydencko-parlamentarny, w którym prezydent mógł zdymisjonować rząd i premiera, lecz nie mógł rozwiązać parlamentu ${ }^{152}$.

Sytuacja formalnie uległa zmianie (w wyniku tzw. pomarańczowej rewolucji) 8 grudnia 2004 r., zaś faktycznie 1 stycznia 2006 r., kiedy przyjęto (z czasem wprowadzone w życie) zmiany i poprawki do Konstytucji Ukrainy ${ }^{153}$. Nie zmieniły one konstytucyjno-prawnego statusu prezydenta jako głowy państwa, lecz znacząco wpłynęły na zawężenie jego kompetencji, zwłaszcza w kwestii formowania rządu i odpowiedzialności rządu przed prezydentem (ustalono, że rząd jest kolektywnie odpowiedzialny tylko przed parlamentem ${ }^{154}$ ). Rząd przekształcił się z instytucji podporządkowanej prezydentowi i kontrolowanej przez niego w samodzielny organ państwowej władzy wykonawczej, którego działalność zaczęła regulować obowiązująca wówczas Ustawa „O Radzie Ministrów Ukrainy”"155. Nawet jeśli parlament zatwierdzał na stanowisku premiera, który ideologicznie i partyjnie zajmował stanowisko przeciwne do prezydenta, to ten ostatni był jednak zmuszony zaakceptować zaproponowaną nomina$c_{j e ̨}^{156}$. Od prezydenta do premiera przesunęty się kompetencje mianowania na stanowiska i zwalniania zwierzchników centralnych organów władzy wykonawczej, którzy nie wchodzili w skład gabinetu, a także w kwestii przedstawienia do rozpatrzenia przez parlament kandydatur poszczególnych członków gabinetu rządowego ${ }^{157}$. Prezydent otrzymał jednocześnie prawo do rozwiązywania parlamentu, jeżeli ten ostatni nie byłby w stanie sformować rządu. Oprócz tego reforma konstytucyjna doprowadziła do „przywrócenia” tych przepisów Konstytucji, które zapisane były w niej

152 M. Shugart, Comparative Executive-Legislative Relations, [w:] The Oxford Handbook of Political Institutions, red. R. Rhodes, S. Binder, B. Rockman, Oxford 2006, s. 357.

153 Про внесення змін до Конституиії України: Закон України від 8 грудня 2004 року № 2222-IВ, „Відомості Верховної Ради України (ВВР)” 2005, Vol. 2, s. 44.

154 Również Radzie Najwyższej Ukrainy przekazano takie uprawnienia, jak mianowanie na podstawie propozycji prezydenta premiera, ministra obrony, ministra spraw zagranicznych, mianowanie na podstawie propozycji premiera pozostałych członków gabinetu rządowego, przewodniczących Komitetu Antymonopolowego, Państwowego Komitetu Telewizji i Radiofonii oraz Funduszu Majątku Państwowego, zwalnianie wymienionych osób ze stanowisk, rozstrzyganie w sprawie dymisji premiera i członków gabinetu rządowego.

155 Rządowi nadano prawo do niezależnego wyznaczania listy centralnych organów władzy wykonawczej oraz mianowania i zwalniania ze stanowisk ich szefów, którzy nie wchodzii w skład rządu, a także mianowania i zwalniania ze stanowisk wiceministrów. Rozszerzone zostały też uprawnienia gabinetu w kwestii kierowania i koordynacji działalności organów władzy, które nie były mu bezpośrednio podporządkowywane (Komitet Antymonopolowy, Państwowy Komitet Telewizji i Radiofonii, Fundusz Majątku Państwowego). Dokładnie zob.: Про Кабінет Міністрів Украӥни: Закон Украӥни від 16 травня 2008 р. № 279-BI, „Відомості Верховної Ради України (ВBP)” 2008, Vol. 25, s. 241. Ustawa straciła moc prawną w październiku 2010 r. na mocy skasowania poprawek do Konstytucji z 2004 r., a także przywrócenia Konstytucji w redakcji z 1996 r. W rezultacie zaczęła obowiązywać nowa ustawa „O Radzie Ministrów Ukrainy”. Dokładnie zob.: Про Кабінет Міністрів України: Закон України від 7 жовтня 2010р. № 2591-BI, „Відомості Верховної Ради України (ВВР)” 2011, Vol. 9, s. 58.

D. Boban, „Minimalist” Concepts..., s. 164.

Р. Павленко, Криза пострадянського парламентаризму? Напрям подальиої конституиійної реформи в Україні, „Вибори та демократія” 2006, Vol. 3, nr 9, s. 28-39. 
przedtem (poczynając od 1996 r.), lecz faktycznie nie obowiązywały, w szczególności procedury kontrasygnacji - zatwierdzania dekretu prezydenta podpisami premiera i ministra odpowiedzialnego za wykonanie dekretu. Jednakże niejednoznaczność sformułowań odpowiednich przepisów oraz różne ich interpretowanie przez różne instytucje władzy stało się faktycznie przyczyną konfliktów między nimi, w szczególności pomiędzy prezydentem i premierem ${ }^{158}$ (przejawiło się to szczególnie ostro w okresie prezydentury W. Juszczenki i premierostwa J. Tymoszenko, prezydentury W. Juszczenki i premierostwa W. Janukowycza, a także w niedługim okresie prezydentury W. Janukowycza i premierostwa J. Tymoszenko). Ogólnie rzecz biorąc, w wyniku z jednej strony wzmocnienia kompetencji premiera, zaś z drugiej strony osłabienia kompetencji prezydenta - czemu dodatkowo sprzyjały kolejne (w tym przedterminowe) wybory parlamentarne w 2006 i 2007 r., przeprowadzone według systemu proporcjonalnego, co istotnie ograniczyło frakcjonalizację ukraińskiego parlamentu - półprezydencki system rządów formalnie przesunął się od prezydencjalizowanej prezydencko-parlamentarnej odmiany ku wzorcowi parlamentarno-prezydenckiemu (który w politologii porównawczej przyjęło się nazywać gabinetowo-prezydenckim), z prerogatywami prezydenta do rozwiązania parlamentu.

30 września 2010 r. Sąd Konstytucyjny Ukrainy - w znacznej mierze pod wpływem nacisków wybranego 7 lutego 2010 r. prezydenta W. Janukowycza (jedynego prezydenta Ukrainy, którego w drugiej turze poparło mniej niż 50\% wyborców) oraz proprezydenckiej większości w parlamencie - unieważnił postanowienia reformy konstytucyjnej, które zostały przyjęte w 2004 r. ${ }^{159}$ Od tego dnia na Ukrainie zaczęła obowiązywać Konstytucja z 1996 r., czyli prezydencko-parlamentarny półprezydencki system rządów, który znacząco wzmocnił miejsce, rolę i kompetencje prezydenta. Wskutek tego (zwłaszcza po tym, jak w rezultacie wyników wyborów parlamentarnych, przeprowadzonych w $2012 \mathrm{r}$. według mieszanej ordynacji większościowo-proporcjonalnej, siły proprezydenckie uzyskały większość miejsc w parlamencie) faktyczne funkcje i uprawnienia prezydenta Ukrainy przesunęły się od bezpośredniego kierowania administracją i zarządzaniem do funkcji i kompetencji ogólnopolitycznego kierownictwa i kontroli „legalności” działań wszystkich organów władz państwowych, zwłaszcza organów władzy wykonawczej. Między innymi rząd ponownie wszedł w synchroniczno-syntetyczną sferę podporządkowania zarówno prezydentowi, jak i parlamentowi (obydwu instytucjom przywrócono kompetencje do ponoszenia odpowiedzialności za formowanie i ewentualne przedterminowe wstrzymanie kompetencji rządu).

158 В. Карасев, У. Кириенко, Метаморфозы и антиномии политического режима: Украина - 2006-2007, „Мировая экономика і международные отношения” 2008, Vol. 9, s. 58-74; Г. Максак, Парламентские выборы в Украине: конфигурация коалицй, „Палітичная сфера” 2006, Vol. 7, s. 106-113; В. Аитвин, Теорія та практика когабітацї в напівпрезидентських системах Європи, „Освіта регіону: політологія, психологія, комунікації 2011, Vol. 4, s. 140-149.

159 Рішення Конституційного Суду України у справі за конституційним поданням 252 народних депутатів України щодо відповідності Конституції України (конституційності) Закону України „Про внесення змін до Конституції України” віА 8 грудня 2004 року № 2222-IB (справа про Аодержання процедури внесення змін до Конституції України): від 30 вересня 2010 р. № 20рп/2010, [online] http://zakon4.rada.gov.ua/laws/show/v020p710-10. 
Wskutek tego, podobnie jak w okresie prezydentury L. Kuczmy, prezydent W. Janukowycz, będąc formalnie tylko głową państwa, był faktycznie kierownikiem rządu. Przejawiało się to w tym, że premier oraz poszczególni ministrowie byli wyrazicielami konkretnych technicznych i osobistych interesów i nacisków prezydenta. Jednakże siła prezydentów L. Kuczmy i W. Janukowycza według Konstytucji w wersji z 1996 r. faktycznie okazała się nieco różna (na korzyść tego drugiego). Rzecz w tym, że w latach 1996-2004 L. Kuczma konstruował siłę swoich kompetencji ze względu przede wszystkim na frakcjonalizację ukraińskiego parlamentu. Odpowiednio do tego Kuczma umiejętnie wykorzystywał brak w parlamencie stabilnej większości jako instrument, który faktycznie wzmacniał i bez tego formalnie rozległe uprawnienia prezydenta. Dzięki politycznym targom z różnymi frakcjami ukraińskiego parlamentu nie musiał dopuszczać ich przedstawicieli do „klanowo-oligarchicznego” ośrodka władzy państwowej, a co za tym idzie nie miał potrzeby sprowadzania roli opozycji parlamentarnej do roli symbolicznej (bardzo często bowiem proprezydenckie i opozycyjne partie zamieniały się miejscami w parlamencie). Natomiast w latach 2010-2013 W. Janukowycz konstruował siłę swoich kompetencji ze względu na partyjną strukturyzację ukraińskiego parlamentu. Wykorzystywał on obecność w parlamencie stabilnej większości jako instrument, za pomocą którego odbywało się wzmacnianie i bez tego formalnie rozległych kompetencji prezydenta. Jednak prezydent stale musiał dokonywać rotacji w środowisku najwyższej elity politycznej (aby ta ostatnia nie zdołała się istotnie wzmocnić) czy też dopuszczać niektórych przedstawicieli najwyższej elity politycznej do „klanowo-oligarchicznego” („rodzinnego”) ośrodka władzy państwowej, wskutek czego reżim polityczny na Ukrainie w okresie prezydentury W. Janukowycza przybrał cechy autorytaryzmu i neopatrymonializmu. Politycznie (przynajmniej na pewien czas) usunąwszy i zminimalizowawszy w ten sposób wpływ opozycji parlamentarnej, w okresie 2010-2013 prezydent faktycznie uzyskał decydujący wpływ na działalność Rady Najwyższej Ukrainy, rządu, systemu sądownictwa, stając się faktycznie kluczową figurą w funkcjonowaniu systemu rządzenia i całego polityczno-prawnego systemu Ukrainy.

Taka sytuacja utrzymała się od listopada 2013 r. do lutego 2014 r., kiedy na skutek masowych protestów ludności (z pocztku z powodu wstrzymania procesów integracyjnych, a po jakimś czasie wskutek systemowego oporu społeczeństwa - w tym również kosztem ofiar - wobec istniejącego układu politycznego), czyli fenomenu tzw. „Euromajdanu” i „rewolucji godności”, został obalony dyktatorski reżim W. Janukowycza. W rezultacie (jak również w wyniku tego, że została naruszona skonsolidowana jedność dawnej proprezydenckiej większości w parlamencie) system rządów na Ukrainie powrócił 2 marca 2014 r. ${ }^{160}$ do modelu parlamentarno-prezydenckiego

16021 II 2014 r. Rada Najwyższa Ukrainy uchwaliła Ustawę Ukrainy nr 742-VII „O przywróceniu niektórych postanowień Konstytucji Ukrainy”. Następnego dnia, ze względu na to, że ustawa ta nie została podpisana przez prezydenta, parlament przyjął uchwałę „O tekście Konstytucji Ukrainy w redakcji z 28 czerwca 1996 roku, ze zmianami i uzupełnieniami, wprowadzonymi przez ustawy Ukrainy z dnia 8 grudnia 2004 roku nr 2222-IV, z dnia 1 lutego 2011 roku nr 2952-VI, z dnia 19 września 2013 roku nr 586-VII". Zatem od 22 II 2014 r. na terytorium Ukrainy obowiązywały postanowienia Konsty- 
(gabinetowo-prezydenckiego) systemu półprezydenckiego z 2006 r. (formalnie wprowadzonego 8 grudnia 2004 r.) ze zmianami i uzupełnieniami. Równocześnie przyjęto kurs na przyśpieszone przyjęcie nowej Konstytucji ub wniesienie poprawek do obowiązującej Konstytucji Ukrainy z 1996 r. ze zmianami i uzupełnieniami. W tej konstrukcji pod nieobecność legalnie wybranego prezydenta Ukrainy (za poprzednim prezydentem W. Janukowyczem rozesłano międzynarodowy list gończy, chociaż jego faktyczne miejsce pobytu według różnych danych jest ograniczone do terytorium Federacji Rosyjskiej), jego funkcje po raz pierwszy w historii posowieckiej Ukrainy 23 lutego 2014 r. przejął „pełniący obowiązki” Prezydenta Ukrainy, którym - zgodnie z obowiązującą Konstytucją Ukrainy - został przewodniczący ukraińskiego parlamentu O. Turczynow. Rownocześnie na dzień 25 maja 2014 r. wyznaczone zostały przedterminowe wybory prezydenckie, w których zwyciężył w pierwszej turze P. Poroszenko. Jednakże w świetle wydarzeń, które zdeterminowały proces polityczny na Ukrainie po odsunięciu od władzy poprzedniego prezydenta (chodzi tu o agresywne zachowanie odnośnie do niektórych regionów Ukrainy ze strony Rosji i społeczno-polityczne nieporozumienia na terytorium Ukrainy), aktualna pozostała sprawa adekwatnego określenia perspektywicznego systemu rządów na Ukrainie i miejsca w nim instytucji prezydentury.

Równocześnie należy podkreślić, że poczynając od lutego 2014 r. (przynajmniej do oczekiwanego przyjęcia poprawek do Konstytucji Ukrainy z 1996 r.), prezydent Ukrainy jest głową państwa wybieraną w wyborach powszechnych według większościowego systemu absolutnej większości (na kadencję pięcioletnią, nie więcej niż dwie kadencje $\mathrm{z}$ rzędu). Kandydat na prezydenta musi mieć ukończone trzydzieści pięć lat, przez dziesięć ostatnich lat powinien mieszkać na Ukrainie, a także musi znać język ukraiński. Zgodnie z art. 108 Konstytucji Ukrainy kadencja Prezydenta Ukrainy wygasa przedterminowo w razie: dobrowolnej rezygnacji; niemożliwości wykonywania obowiązków ze względu na stan zdrowia; usunięcia ze stanowiska w trybie impeachmentu; śmierci. Kluczowe funkcje, które zostały skupione w ręku prezydenta na Ukrainie, są następujące: gwarantowanie państwowej suwerenności oraz integralności terytorialnej Ukrainy, przestrzegania Konstytucji Ukrainy, praw i swobód człowieka i obywatela, zapewnienie państwowej niepodległości, bezpieczeństwa narodowego i praworządności w państwie. Prezydent Ukrainy reprezentuje państwo wewnątrz kraju i w relacjach międzynarodowych, posiada szereg kompetencji w zakresie wyznaczania i rozpisywania wyborów oraz referendów, a także formowania i funkcjonowania władz państwowych. Równocześnie

tucji przyjętej na piątej sesji Rady Najwyższej Ukrainy 28 VI 1996 r., ze zmianami i uzupełnieniami wprowadzonymi przez ustawy Ukrainy z dnia 8 XII 2004 r. nr 2222-IV, 1 II 2011 r. nr 2952-VI oraz 19 IX 2013 r. nr 586-VII. 1 III 2014 r. ustawa nr 742-VII została opublikowana w specjalnym wydaniu gazety „Hołos Ukrajiny” z podpisem p.o. prezydenta O. Turczynowa. Tak więc nabrała ona mocy prawnej 2 III 2014 r. Dokładniej zob.: Про відновлення дї̈ окремих положень Конституції України: Закон Украӥни від 21 лютого 2014 р. № 742-BII, „Відомості Верховної Ради (ВВР)” 2014, Vol. 11, s. 143; Про текст Конституції України в редакиї 28 червня 1996 року, із змінами і доповненнями, внесеними законами України від 8 грудня 2004 року № 2222-IB, від 1 ^ютого 2011 року № 2952BI, від 19 вересня 2013 року № 586-ВII: Постанова Верховної Ради України від 22 лютого 2014 р. № 750-BII, „ВіАомості Верховної Ради (ВВP)” 2014, Vol. 11, s. 151. 
prezydent Ukrainy nie jest zwierzchnikiem władzy wykonawczej, a jego rola w formowaniu rządu sprowadza się do proponowania kandydatury premiera i poszczególnych ministrów (bez prawa do kolektywnego dymisjonowaia rządu), które musi zatwierdzić parlament (który jednocześnie ma prawo zdymisjonować cały skład Rady Ministrów lub poszczególnych ministrów).

Formułując wnioski, należy zauważyć, że instytucja prezydentury w politycznej historii Ukrainy od początku XX do początku XXI w. znacząco ewoluowała. W rezultacie sposób wybierania prezydenta (od roku 1991 powszechny, a w przekroju historycznym parlamentarny), kompetencje (od 1991 r. większe niż w historycznej retrospektywie), miejsce i rola (od $1991 \mathrm{r}$. ponad całym systemem władzy państwowej, a w przekroju historycznym w systemie władzy państwowej) instytucji prezydentury na Ukrainie po 1991 r. nie odpowiadają praktyce instytucjonalnej i historycznemu doświadczeniu, które kształtowały stanowisko prezydenta na historycznych ziemiach Ukrainy na początku XX w. i w pierwszej połowie tego stulecia. W kontekście systemowym oznacza to, że instytucja prezydentury na Ukrainie była wcześniej w większej mierze skierowana na realizację i aprobację parlamentarnego systemu rządów republikańskich, natomiast w latach 1991-2014 na prezydencki, a nawet półprezydencki system rządów republikańskich.

Powinno to być jednym z istotnych drogowskazów w dalszym reformowaniu systemu rządów na Ukrainie i miejsca w nim prezydenta. Jest oczywiste, że historyczne doświadczenia w zastosowaniu instytucji prezydentury na Ukrainie w większym stopniu wskazują na to, że instytucja ta powinna być reglamentowana i zaaprobowana w warunkach republikańskiego parlamentaryzmu lub parlamentarno-prezydenckiego (gabinetowo-prezydenckiego) półprezydencjalizmu. Odpowiadałoby to nie tylko konceptualnej istocie poszukiwań polityczno-prawnych w zakresie systemu rządów i miejsca w nim instytucji prezydentury na Ukrainie w okresie drugiej połowy XIX i początku XXI w., lecz także instytucjonalnemu (podkreślmy: dość udanemu i stabilnemu) doświadczeniu krajów Europy Środkowo-Wschodniej i Południowo-Wschodniej, które wcześniej znajdowały się w okresie przejściowym, a które będąc lub pragnąc zostać członkami Unii Europejskiej, w sposób zupełnie uporządkowany, systemowy i naturalny zaaprobowały systemy parlamentaryzmu republikańskiego i parlamentarno-prezydenckiego (gabinetowo-prezydenckiego) półprezydencjalizmu.

Narzuca się również wniosek, że - jak świadczą o tym doświadczenia ukraińskiego tworzenia państwa - instytucja prezydentury na Ukrainie miała przeważnie charakter koniunkturalny, albowiem kompetencje, rola i miejsce prezydenta w systemie władzy w państwie (w systemie rządów) zazwyczaj były określane przez konkretne zamiary pewnych sił politycznych lub przez wydarzenia polityczne, które zachodziły na Ukrainie w trakcie różnych etapów jej nowej (na początku i w połowie XX w.) i najnowszej (koniec XX - początek XXI w.) historii. Warto natomiast skoncentrować się na instytucji prezydentury, która będzie wszechstronnie odzwierciedlała istniejące społeczne zapotrzebowanie i całkowicie odpowiadała na wyzwania (w rozumieniu ryzyka/zalet) dalszego reformowania systemu rządów i ogółu systemu politycznego na Ukrainie. 


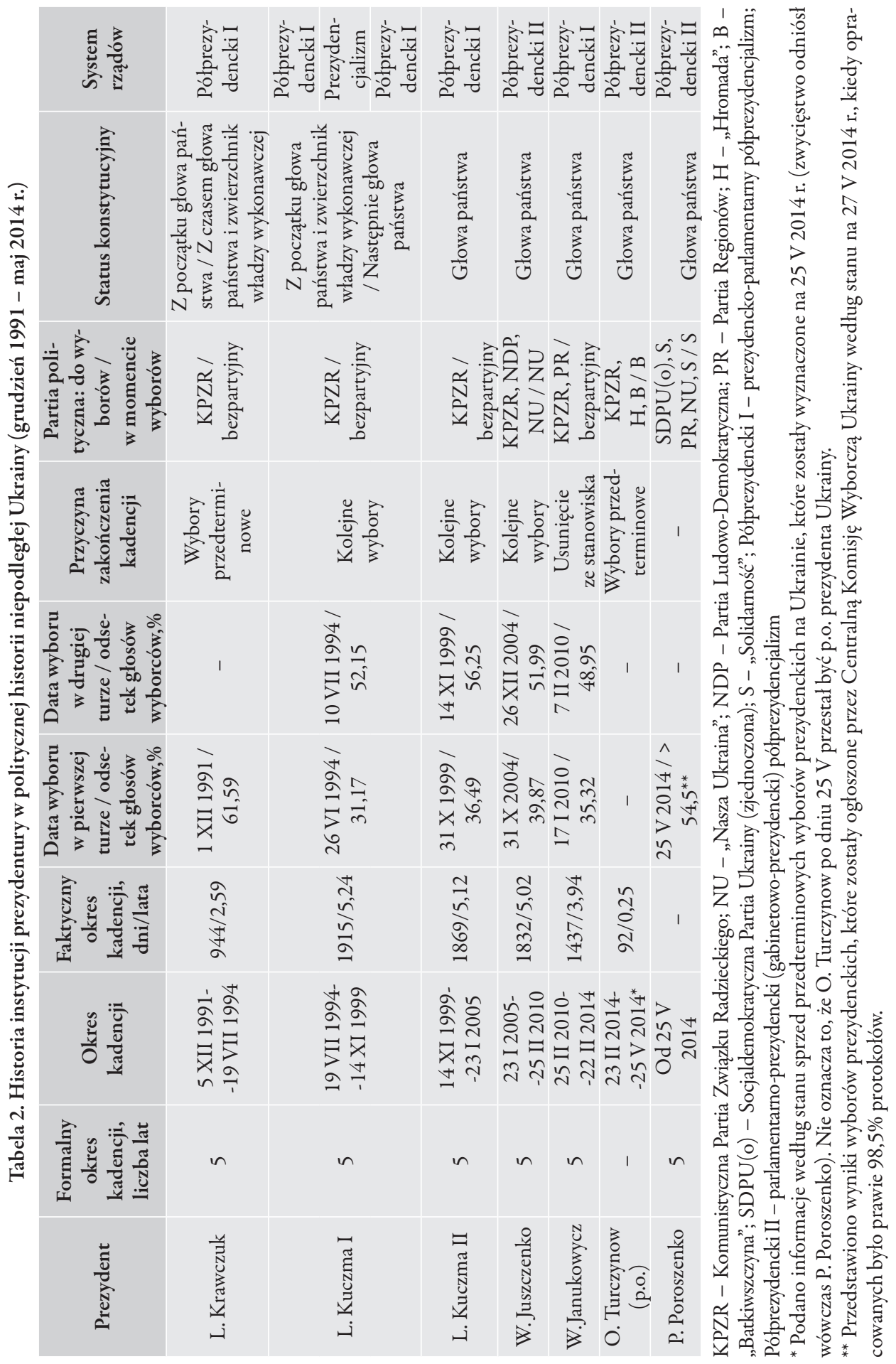




\section{BIBLIOGRAFIA}

Boban D., „Minimalist” Concepts of Semi-presidentialism: Are Ukraine and Slovenia Semi-presidential States?, „Politička misao” 2007, Vol. 44, nr 5.

D’Anieri P., Understanding Ukrainian Politics. Power, Politics, and Institutional Design, Armonk 2007.

Duverger M., A New Political System Model: Semi-Presidential Government, „European Journal of Political Research"1980, Vol. 8, nr2, [online] http://dx.doi.org/10.1111/j.1475-6765.1980. tb00569.x.

Eaton K., Review: Parliamentarism versus Presidentialism in the Policy Arena, „Comparative Politics" 2002, Vol. 32, nr 3, [online] http://dx.doi.org/10.2307/422371.

Elgie R., The Classification of Democratic Regime Type: Conceptual Ambiguity and Contestable Assumptions, „European Journal of Political Research” 1998, Vol. 33, nr 2, [online] http:// dx.doi.org/10.1111/1475-6765.00381.

Jung-Hsiang T., Sub-types of Semi-presidentialism and Political Deadlock, „French Politics” 2008, Vol. 6, nr 1, [online] http://dx.doi.org/10.1057/palgrave.fp.8200140.

Krouwel A., Measuring Presidentialism and Parliamentarism: An Application to Central and East European Countries, „Acta Politica” 2003, Vol. 38, nr 4, [online] http://dx.doi. org/10.1057/palgrave.ap.5500041.

Lindner R., Die Ukraine zwischen Transformation und Selbstblockade. Wirtschaft, Politik und Parteien; regionale und ausländische Interessen vor den Parlamentswablen 1998, Ebenhausen Stiftung Wissenschaft und Politik 1998.

Linz J.J., Presidential or Parliamentary Democracy: Does It Make a Difference?, [w:] The Failure of Presidential Democracy. Comparative Perspectives, red. tenże, A. Valenzuela, Baltimore 1994.

Matsuzato K., Semipresidentialism in Ukraine: Institutionalist Centrism in Rampant Clan Politics, „Democratization” 2005, Vol. 13, nr 1.

Protsyk O., Constitutional Politics and Presidential Power in Kuchma's Ukraine, „Problems of Post-Communism” 2005, Vol. 52, nr 5, [online] http://dx.doi.org/10.1080/10758216.20 05.11052212 .

Protsyk O., Ruling with Decrees: Presidential Decree Making in Russia and Ukraine, „Europe-Asia Studies” 2004, Vol. 56, nr 5, [online] http://dx.doi.org/10.1080/09668130410002 35083.

Sartori G., Comparative Constitutional Engineering. An Inquiry into Structures, Incentives and Outcomes, London 1994.

Shugart M., Comparative Executive-Legislative Relations, [w:] The Oxford Handbook of Political Institutions, red. R. Rhodes, S. Binder, B. Rockman, Oxford 2006.

Shugart M., Carey J., Presidents and Assemblies. Constitutional Design and Electoral Dynamics, Cambridge-New York 1992.

Siaroff A., Comparative Presidencies: The Inadequacy of the Presidential, Semi-presidential and Parliamentary Distinction, „European Journal of Political Research” 2003, Vol. 42, nr 3, [online] http://dx.doi.org/10.1111/1475-6765.00084. 
Stepan A., Skach C., Constitutional Frameworks and Democratic Consolidation. Parliamentarism versus Presidentialism, „World Politics” 1993, Vol. 46, nr 1, [online] http://dx.doi. org/10.2307/2950664.

Wilson A., Ukraine: Two Presidents and their Powers, [w:] Postcommunist presidents, red. R. Taras, Cambridge-New York 1997.

Wolczuk K., The Moulding of Ukraine. The Constitutional Politics of State Formation, Budapest 2002.

Агафонов С., Історичний розвиток інституту глави держави в Україні, „Право України” 2001, Vol. 7.

Агафонов С., Правовий статус Президента Украӥни, „Право України” 2000, Vol. 9.

Багатопартійна украӥнська держава на початку XX століття: партійні документи перших українських політичних партій, Київ 1992.

Байхемьт Т., Павленко Р., Президентські вибори і конституційна реформа, [w:] Президентські вибори та Помаранчева револючія: вплив на трансформачійні прочеси в Украйні, Київ 2005.

Балагура О., Институт президентства в Украине: практика становлении, „Пробкеми права на змамі тисячоліть" 2001.

Барабаш Й., Імпічмент як форма конституиійно-правової відповідальності $і$ засіб урегулювання державно-правових конфліктів, „Проблеми законності” 2008, Vol. 96.

Барабаш Й., Президент у змішаних республіках: деякі питання конституційно-правової теорії та практики, „Право України” 2012, Vol. 8.

Безсмертний Р., Президент України і Верховна Рада України, „Віче” 2000, Vol. 7, nr 100.

Берназюк I., Послання Президента України до народу та до Верховної Ради України як офіційні документи (акти) глави держави, „Форум права” 2010, Vol. 4.

Берназюк I., Реалізачія Президентом Украӥни права вето шуодо прийнятих Верховною Радою України законів: деякі аспекти, „Порівнямьно-аналітичне право” 2013, Vol. 1.

Бєлов А., Бисага I., Конституційно-правове регулювання інституту президентства в Україні та Францї, Ужгород 2007.

Бікенчук П., Капемюшний В., Георгій Андрузький: провидещь, патріот, конститущіоналіст, „Вісник Академії праці і соціальних відносин Федерації профспілок України” 2002, Vol. 2, nr 15.

Болдирєв С., Ребриш Б., Підстави проведення імпічменту глави держави за Конституцією України: перспективи удосконалення, „Аержавне будівництво та місцеве самоврядування" 2012, Vol. 23.

Борисов Н., Институт Президента Украинь: долгий путь к институщионализации, „Грани” 2013, Vol. 3.

Бурчак Ф., Президент Украӥни, Київ 1997.

Бурчак Ф., Погорікко В., Конституційно-правовий статус Президента України, [w:] Конституційне право України, red. В. Тація, В. Погорілка, І. Тодики, Київ 1999.

Вавженчук С., Виконавча влада - Президент Украйни: конституційно-правові аспекти структурної взаємодї, „Аержава і право” 2005, Vol. 30. 
Ведомости Съезда народньх депутатов СССР и Верховного Совета СССР, 1990, Vol. 7.

Веніславський Ф., Роль Президента України в механізмі забезпечення взаємодії законодавчої і виконавчої гілок влади, „Нова політика” 1998, Vol. 1.

Волощук О., Інститут президента у Францї, Росії та Україні: конститущійні норми і політична практика: монографія, Чернівці 2009.

Волощук О., Конститучійні проблеми взаємовідносин Президента та виконавчої влади, „Держава і право” 2004, Vol. 26.

Волощук О., Місце Президента у механізмі державної влади, „Бюлетень Міністерства Юстиції України” 2011, Vol. 12.

Волощук О., Повноваження президента Украйни щодо судової влади, „Науковий вісник Чернівецького університету. Правознавство” 2011, Vol. 575.

Волощук О., Президент - активний учасник законодавчого прочесу (порівняльний аналіз конституційно-правових норм Франції, Росї та України), „Науковий вісник Ужгородського університету. Право” 2002, Vol. 1.

Волощук О., Теоретичні та практичні проблеми організачї інституту виборів Президенmа України, „Вісник Центрамьної Виборчої Комісії” 2009, Vol. 1, nr 15.

Галаган $\Lambda$., Президент у системі влади за різних форм державного правління, „Політичний менеджмент" 2011, Vol. 4.

Гапоненко В., Суперечності інституту президентства: теоретичні засади та уроки для України, „Політичний менеАжмент” 2011, Vol. 5.

Гнілорибов В., Проблеми взаємовідносин Верховної Ради України та Президента України, [w:] Парламентаризм в Україні: теорія і практика, Київ 2001.

Головатенко В., Окремі аспекти конституиійно-правового статусу Президента України, „Право України” 1999, Vol. 5.

Головатенко В., Право вето Президента Украӥни: складова механізму стримувань і противаг чи дестабілізуючий чинник законотворення?, „Українське право” 2000, Vol. 1.

Горбатюк В., Інститут президентства в Україні: історико-правовий аспект, „Часопис Київького університету права” 2011, Vol. 2.

Грушевський М., На порозі нової України (фрагменти), [w:] Громадянин - Аержава - Громадянське виховання. Антологія, red. М. Рагозін, О. Сухомиинська, Аонецьк 2001.

Гулиев А., Институт президентства в противодействии международному терроризму: сравнительно-правовой анализ законодательства Украины и Азербайджанской Республики, Киев 2012.

Ааниляк О., Порівняльний аналіз механізмів стримувань і противаг між Президентом, парламентом та Урядом Украйни у владних моделях 1996 та 2004 років, „Вісник Національної академії державного управління. Політологія і право” 2011, Vol. 2, nr 2.

Аем'яненко Б., Генезис інституту президентства в Україні: попегеdні підсумки президентсъкої каденщї В. Ющенка, „Сучасна українська політика: політики і політологи про неї: зб. наук. праць” 2010, Vol. 19.

Аерев'янко С., Про уточнення повноважень Президента України щодо призначення/проголомення всеукраїнського референдуму в оновленій Конституціӥ України, „Вісник Центрацьної Виборчої Комісії” 2009, Vol. 2-3, nr 16-17.

Аіус Н., Інститут імпічменту в Україні, Францї та Російській Федерацї: порівняль- 
но-правовий аспект, „Науковий вісник Ужгородського національного університету. Право" 2007, Vol. 8.

Аорошенко А., Аоба Центральної Ради - Історія Украӥни. 1917-1923 рр., Vol. 2, Ужгород 1932.

Аорошенко А., Історія України. 1917-1923 рр. Украӥнська гетьманська держава 1918 р., Ужгород 1930.

Арагоманов М., Пегеднє слово до „Громади”, [w:] tenże, Вибрані твори. Збірка політичних творів з примітками, Прага-Нью-Йорк 1937.

Аудник О., Трансформауія інституту президентства в країнах СНА (2005-2006 роки), „Політичний менеАжмент” 2007.

Жалій Т., Правовий статус глав держав в Украӥні та Російській Федерачіӥ: порівняльний аналіз, „Науковий вісник Херсонського державного університету. Юридичні науки” 2013, Vol. 1.

Жикяєв І., Послання Президента Украӥни як інструмент державної політики, „Стратегічні пріоритети" 2007, Vol. 1, nr 2.

Жимяєв І., Послання Президента України як інструмент стратегічного управління, „Економічний часопис" 2006, Vol. 5-6.

Житник О., Інститут глави держави в політико-правовій думщі доби украӥнського національного відродження (друга половина XIX cm. - 1917р.), „Часопис Академії адвокатури України" 2010, Vol. 9, nr 4.

Жук Н., Парламент, президент, уряд: через взаємостримування до рівноваги. Монографія, Харків 2007.

Зазнаев О., Классификачии президентской, парламентской $і$ полупрезидентской систем, [w:] М. Фарукшин, Аинамика политических систем и международных отношениях, Vol. 1, Казань 2006.

Закон про Виділ Украӥнської Ради 4 січня 1919 р., [w:] М. Аозинський, Галичина в рр. 19181920, Прага 1922.

Закон про Аержавну Народну Раду Української Народної Республіки від 12 листопада 1920 року, „Вісник Аержавних Законів Аля всіх земель Української Народної Республіки” 1920, 19 XI, Vol. 2.

Закон про тимчасове Верховне Управління та порядок законодавства в Украйнській Народній Республічі від 12 листопада 1920 р., [w:] Конституційні акти України. 1917-1920. Невідомі конституції України, Київ 1992.

Заяць Н., Теоретико-правові проблеми інституту президентства в механізмі реалізацї державної влади в Україні, „Право України” 2009, Vol. 6.

Зелінська М., Етапи трансформацї інституту президентства в Україні, „Політичний менеАжмент" 2010, Vol. 1.

Зелінська М., Можливі моделі розвитку інституту президентства в Украӥні, „Політичний менеджмент" 2007, Vol. 3.

Зозуля О., Інститут президентства як об’єкт сучасної конститущійної реформи в Україні, „Форум права” 2010, Vol. 1.

Зозуля О., Канцелярія Президента України: правові засади побудови апарату глави держави, „Форум права” 2008, Vol. 2. 
Зозуля О., Правовий статус Президента України як глави держави і глави виконавчої влади, „Науковий вісник Ужгородського національного університету. Право” 2008, Vol. 11.

Зозуля О., Секретаріат Президента України: нормативно-правові засади організаціі та діяльності: монографія, red. О. Марцемяк, Харків 2008.

Зозуля О., Теорія та практика взаємодіі Секретаріату Президента України з Верховною Радою України, „Право і безпека” 2007, Vol. 6, nr 2.

Інститут Президента України в системі державної влади України: матеріали наукової конферениї, Київ 2014.

Карасев В., Кириенко У., Метаморфозы и антиномии политического режима: Украина 2006-2007, „Мировая экономика і международные отношения” 2008, Vol. 9.

Кармазіна М., Еволючія структури президентського Секретаріату, „Політичний менеАжмент" 2009, Vol. 3.

Кармазіна М., Президентство: украӥнський варіант, Київ 2007.

Кафарський В., На відміну від елітного акиіонерного клубу і від монарха. Політичні партї i Президент: шляхи співпраці, „Віче” 2006, Vol. 17-18.

Кирисо-Мефодіївське товариство, Київ 1990.

Ковриженко А., Інститут вето: зарубіжний досвід, начіональне законодавство і практика, пропозиції, Київ 2009.

Конституция (Основной Закон) Союза Советских Социалистических Республик, „Свод законов СССР” 1990, Vol. 3.

Конституційне право Украӥни, red. В. Погорікко, Київ 1999.

Конституційний договір міз Верховною Радою України та Президентом Украӥни про основні засади організачї та функиіонування державної влади і місцевого самоврядування в Украйні на період до прийняття нової Конститущії Украӥни: від 8 червня 1995 р., „ВіАомості Верховної Ради України (ВВР)” 1995, Vol. 18.

Конститущія незалежної України, Vol. 1, Київ 1995.

Конституція (Основний Закон) Украйни. 20 квітня 1978 р. (із змінами і доповненнями, внесеними станом на 21 вересня 1994 р.), Київ 1994.

Конституція України. Прийнята на п’ятій сесї̈ Верховної Ради України 28 червня 1996 р., Київ 1997.

Конституція Української Народної Республіки (Статут про державний устрій, права і вільності УНР), [w:] П. Христюк, Замітки іматеріали до історії української революyï 1917-1920рp., Vol. 2, Прага 1921.

Кордун О., Ващенко К., Павленко Р., Особливості виконавчої влади в пострадянській краӥні. Монографія, red. О. Кордуна, Київ 2000.

Костів В., Конституиійні акти відновленої украӥнської держави 1917-1919 років і їхня політично-державна якість, Торонто 1964.

Крейденко В., Інститут президентства в Україні: порівняльний аналіз 2004-2012 рр., „Ефективність державного управління” 2012, Vol. 30.

Кресіна І., Коваленко А., Балан О., Інститут імпічменту: порівняльний політико-правовий аналіз, Київ 2004.

Кривенко А., Президент Украӥни: конституційно-правовий статус, „Віче” 1993, Vol. 12. 
Кудряченко А., Институт президентства в Украине: реалии конститущионно-правового статуса, „Государство и право” 1998, Vol. 3.

Аазарев Б., Об изменениях в правовом статусе Президента СССР, „Государство и право” 1991, Vol. 8.

Аазарев Б., Президент СССР, „Государство и право” 1990, Vol. 7.

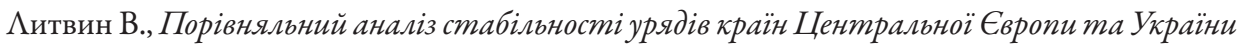
(дис. ... канд. політ. наук: 23.00.02: захищ. 09.04.2010: затверджена 06.10.2010), Вид. Аьвівський національний університет імені Івана Франка, Аьвів 2010.

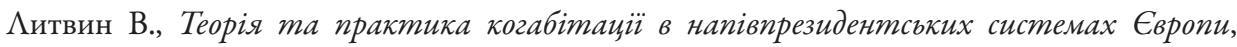
„Освіта регіону: політологія, психологія, комунікаціі” 2011, Vol. 4.

Аитвин М., Науменко К., Історія ЗУНР, Аьвів 1995.

Мазур А., Правові акти президентів України і Росї̈ та їх класифікаиіл: теоретико-правовий аспект, „Вісник Нац. ун-ту внутр. справ” 2004, Vol. 27.

Макаров Г., Нормотворча діяльність глави держави: зарубіжний досвід та вітчизняна практика, „Стратегічні пріоритети” 2009, Vol. 1, nr 10.

Максак Г., Парламентские выьбры в Украине: конфигурация коалиций, „Палітичная сфера” 2006, Vol. 7.

Манюк П., Право вето президента України у контексті правової охорони конституиії України, „Порівняльно-аналітичне право” 2013, Vol. 3, nr 2.

Мартинюк Р., Аналіз функціональної природи інституту президента в Україні, „Часопис Київського університету права" 2008, Vol. 2.

Мартинюк Р., Президент Украӥни в системі стримувань і противаг на сучасному етапі, „Підприємництво, господарство і право” 2008, Vol. 8.

Мартинюк Р., Проблеми визначення конституційно-правового статусу Президента України в умовах зміманої форми правління, „Право України” 2009, Vol. 5.

Мацкевич М., Конститущійне законодавство в ЗУНР: історико-правові аспекти, „Право України" 2011, Vol. 2.

Мельниченко В., Інститут Президента в Україні: стан та перспективи розвитку, „Право України” 2009, Vol. 12.

Мельниченко В., Пцахотнюк Н., Повноваження Президента України у контексті конституційної реформи: структура, зміст, характер, „Бюлетень Міністерства Юстиції України” 2005, Vol. 12.

Музиченко П., Історія держави і права України, Київ 2000.

Основний закон „Самостійної України” Спілки народу украӥнського, [w:] Iсторія української конституції, red. А. Слюсаренко, М. Томенко, Київ 1997.

Павленко Р., Криза пострадянського парламентаризму? Напрям подальшої конститущійної реформи в Україні, „Вибори та демократія” 2006, Vol. 3, nr 9.

Пахомова М., Формування інституту президентськоӥ влади в Україні, „Наукові праці. Науково-методичний журнал” 2004, Vol. 33, nr 20: Політичні науки.

Паречина С., Институт президентства: история и современность, red. Е. Матусевич, Минск 2003.

Пігенко В., Пушак Т., Президентська, парламентська та змішана форма правління: досвід демократій Центрально-Східної Європи у контексті становлення системи державного 
управління в Украйні, Програма сприяння парламенту. Програма розвитку законотворчої політики 2003.

Пиахотнюк П., Мемьниченко В., Iнститут президенства в Украӥні: становлення та розвиток: монографія, Київ 2004.

Погорікко В., Інститут президентства в Україні, [w:], Державотворення і правотворення в Україні: досвід, проблеми, перспективи. Монографія, red. І. Шемшученко, Київ 2001.

Погорікко В., Теоретичні проблеми конститучійного статусу Президента України, [w:] Проблеми реалізачї̈ Конституиї України: теорія і практика. Монографія, red. В. Погорікко, Київ 2003.

Поліщук О., Конститущійно-політична модернізація інституту президента в Украӥні, „Вісник ХНУ імені В.Н.Каразіна. Питання політології 2013, Vol. 1073.

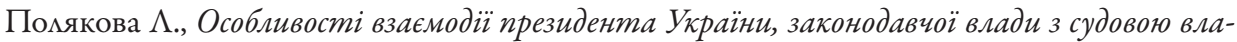
дою (1991-2004 pp.), „Наукові праці історичного факультету Запорізького націонацьного університету" 2013, Vol. 35.

Потапенко В., Президент України і судова влада: деякі аспекти взаємодї, „Пробцеми законності” 2010, Vol. 110.

Приймак Т., Конституиійний проект М. Грушевського з 1905 р., „Український історичний журнал” 1991, Vol. 1.

Про вибори Президента Украйнської РСР: Постанова Верховної Ради Украйнської РСР від 5 липня 1991 р., „Відомості Верховної Ради УРСР (ВВР)” 1991, Vol. 33.

Про відновлення дї окремих положень Конституцї України: Закон Украӥни від 21 лютого 2014 p. № 742-BII, „Відомості Верховної Ради (ВВР)” 2014, Vol. 11.

Про внесення змін до Конститущії України: Закон України від 8 грудня 2004 року № 2222-IB, „Відомості Верховної Ради України (ВВР)” 2005, Vol. 2.

Про всеукрайнський та місиеві референдуми: Закон Украӥни від 3 липня 1991 р. № 1286-XII, „Відомості Верховної Ради УРСР (ВВР)” 1991, Vol. 33.

Про заснування поста Президента СРСР і внесення змін та доповнень до Конституцї (Основного Закону) СРСР: Закон Союзу Радянських Соціалістичних Республік № 1360-I від 14.03.90, [online] http://zakon4.rada.gov.ua/laws/show/v1360400-90.

Про заснування поста Президента Украйнської РСР і внесення змін та доповнень до Конститущії (Основного Закону) Української РСР: Закон Української Радянської Соціалістичної Республіки від 5 липня 1991 р., „Відомості Верховної Ради УРСР (ВВР)” 1991, Vol. 33.

Про Кабінет Міністрів України: Закон Украӥни від 16 травня 2008 р. № 279-ВI, „ВіАомості Верховної Ради України (ВВР)” 2008, Vol. 25.

Про Кабінет Міністрів України: Закон України від 7 жовтня 2010 р. № 2591-BI, „ВіАомості Верховної Ради України (ВВР)” 2011, Vol. 9.

Про керівничтво Кабінетом Міністрів Украӥни: Указ Президента Украӥни від 27 вересня 1993 р., „Голос України” 1993, 28 III.

Про Концепцію нової Конституиї України: Постанова Верховної Ради Украӥнської РСР від 19 червня 1991 р., „Відомості Верховної Ради УРСР (ВВР)” 1991, Vol. 35.

Про Президента Украӥнської РСР: Закон Української Радянської Сочіалістичної Республіки від 5 липня 1991 р., „Відомості Верховної Ради УРСР (ВВР)” 1991, Vol. 33. 
Про текст Конституції України в гедакщії 28 червня 1996 року, із змінами і доповненнями, внесеними законами України від 8 грудня 2004 року № 2222-IB, від 1 лютого 2011 року № 2952-BI, від 19 вересня 2013 року № 586-ВII: Постанова Верховної Ради України від 22 лютого 2014 p. № 750-BII, „Відомості Верховної Ради (ВВР)” 2014, Vol. 11.

Рішення Конститущійного Суду Украӥни у справі за конституційним поданням 252 народних депутатів України щуодо відповідності Конституції України (конституційності) Закону України „Про внесення змін до Конституцї України” від 8 грудня 2004 року № 2222-ІВ (справа про додержання прочедури внесення змін до Конституцї Українu): від 30 вересня 2010 p. № 20-pn/2010, [online] http://zakon4.rada.gov.ua/laws/show/ v020p710-10.

Рудик П., Ао питання нового статусу Президента України в контексті конституційних змін, „Часопис Київського університету права” 2008, Vol. 2.

Рязанцев А., Роль института президентства в процессе формирования исполнительной власти в России и Украине (сравнительньцй анализ), „Вестник ВГУ: История. Политомогия. Социология" 2013, Vol. 1.

Сахаров Н., Институт президентства в современном мире, Москва 1994.

Селіванов А., Суслов В., Право президентського вето у контексті відносин з парламентом, „Голос України” 1996, Vol. 105-106.

Серьогіна С., Оптимізачія статусу президента як ключова ланка конституційної реформи України, „Право України” 2009, Vol. 6.

Серьогіна С., Теоретико-правові та організаційні засади функціонування інституту президентства в Україні: монографія, Харків 2001.

Сінельник С., Аискречійні повноваження президента Украйни в контексті проведення конституційної реформи, „Вісник Запорізького національного університету. Юридичні науки" 2009, Vol. 1.

Скребец Е., Практика применения института вето главы государства и стабильность политической системь Украины, „Вестник СевГТУ. Политология” 2003, Vol. 52.

Совгиря О., Інститут контрасигнування актів глави держави в Украйні: правова природа та проблеми законодавчого регулювання, „Вісник Київського національного університету імені Тараса Шевченка. Юридичні науки” 2010, Vol. 85.

Сталин И., Вопросы ленинизма, Москва 1945.

Старків I., Історико-правові витоки інституту президентства в Україні та світі, „Форум права" 2012, Vol. 4.

Стерчо П., Картапо-Українська Аержава. Ао історії визвольної боротьби карпатських украӥниів у 1919-1939 роках, Аьвів 1994.

Стецюк П., Станіслав Аністрянський як конституиіоналіст, Аьвів 1999.

Стрижова I., Iнститут президентства на пострадянському просторі, „Гікея” 2011, Vol. 49. Сухонос В., Інститут глави держави в конституційному праві. Монографія, Суми 2011.

Сухонос В., Інститут глави держави в Україні 1917-1921 років, „Вісник ЦВК” 2008, Vol. 4, nr 14.

Тимчасовий основний закон про державну самостійність украӥнських земель бувшої Австро-Угорськой монархї, ухвалений Украӥнською Начіональною Радою на засіданні 13 лиcmonada 1918 p., [w:] М. Аозинський, Галичина в рр. 1918-1920, Прага 1922. 
Тищик Б., Конститущійне законодавство Західно-Української народні Республіки, „Науковий Збірник Українського Вільного Університету” 1995, Vol. 17.

Ткаченко О., Вето Президента: основи, практика, „Голос України” 1999, Vol. 142.

Тодика І., Президент Украйни: конституиійно-правовий статус: монографія, Харків 1999.

Тодика И., Яворский В., Президент Украиньь: конституционно-правовой статус: монография, Харьков 1999.

Томенко М., Інституту президентства в українській історико-політичній думці, „Українська перспектива: історико-політологічні підстави сучасної державної стратегії” 1995 , Vol. 2.

Трійняк Т., Аеякі аспекти конституційної відповідальності Президента України, [w:] Аругі конституційні читання, Харків 2009.

Франко I., „Громада” $i$ „за друга” сегед украӥнського народу в Галичині $і$ на Буковині, [w:] tenże, Зібрання творів. У 50 m., Київ 1984, Vol. 44, nr 1.

Христюк П., Замітки і матеріали до історії української революуії 1917-1920 рр., Прага 1921.

Цвік М., Жук Н., Аинаміка президентської влади в Україні, „Вісник академії правових наук України" 2007, Vol. 3, nr 46.

Цвік М., Процюк I., Про державно-правову природу влади Президента Украӥни в системі розподілу влад, „Проблеми конституційного права” 1999, Vol. 1.

Шаповал В., Головатенко В., Інститут глави держави в українському конституціоналізмі кіния XIX - початку XX cm., „Вісник Академії правових наук України” 1997, Vol. 2, nr 9.

Шаповах В., Вищі органи сучасної держави. Порівняльний аналіз, Київ 1995.

Шаповал В., Статус Президента и исполнительная власть в Украине, [w:] Проблемьь гармонизачии законодательства Украинь і стран Европьь, red. Е. Кубко, В. Цветкова, Киев 2003.

Шатимо В., Институт президентства в механизме государственной власти зарубежньц стран и Украиныь, „TEISE” 2014, Vol. 90.

Шатияо В., Нормативно-правовые и другие акты президента Украины в механизме реализации государственной власти, „TEISE” 2013, Vol. 87.

Шатіко В., Інститут глави держави: його місце в украӥнському конституціоналізмі XIX поч. XX cm., „Віче” 1999, Vol. 10.

Шатіко В., Інститут президентства в системі державної влади України, Київ 2004.

Юзьков $\Lambda$., Від Аекларацї про державний суверенітет України до Концепціӥ нової Конститущії України, [w:] Конституція незалежної України, Vol. 1, red. С. Головатий, Київ 1995.

Ttumaczenie Przemystaw Tomanek

Dr Witalij ŁYTWYN - doktor nauk politycznych, asystent w Katedrze Politologii Lwowskiego Uniwersytetu Narodowego im. Iwana Franki. 